\title{
Angioregulatory microRNAs in Colorectal Cancer
}

\author{
Mohammad Hasan Soheilifar $\left.{ }^{1}{ }^{(}\right)$, Michael Grusch ${ }^{2}{ }^{(0)}$, Hoda Keshmiri Neghab ${ }^{3} \mathbb{C D}^{\text {, }}$ \\ Razieh Amini ${ }^{1, *}$, Hamid Maadi ${ }^{4}$, Massoud Saidijam ${ }^{1}$ and Zhixiang Wang ${ }^{4, *}$ (D) \\ 1 Research Center for Molecular Medicine and Genetics, School of Medicine, Hamadan University of Medical \\ Sciences, Hamadan 65178, Iran; soheilih@gmail.com (M.H.S.); sjam110@yahoo.com (M.S.) \\ 2 Department of Medicine I, Institute of Cancer Research, Medical University of Vienna, 1090 Vienna, Austria; \\ michael.grusch@meduniwien.ac.at \\ 3 Department of Photo Healing and Regeneration, Medical Laser Research Center, Yara Institute Academic \\ Center for Education, Culture and Research (ACECR), Tehran 1315795613, Iran; hodakeshmiri@ut.ac.ir \\ 4 Department of Medical Genetics, and Signal Transduction Research Group, Faculty of Medicine and \\ Dentistry, University of Alberta, Edmonton, AB T6G 2H7, Canada; hmaadi@ualberta.ca \\ * Correspondence: Aminra14@gmail.com (R.A.); zhixiang.wang@ualberta.ca (Z.W.)
}

Received: 5 December 2019; Accepted: 23 December 2019; Published: 26 December 2019

\begin{abstract}
Colorectal cancer (CRC) is one of the leading causes of cancer mortality. Angiogenesis is a rate-determining step in CRC development and metastasis. The balance of angiogenic and antiangiogenic factors is crucial in this process. Angiogenesis-related genes can be regulated post-transcriptionally by microRNAs (miRNAs) and some miRNAs have been shown to shuttle between tumor cells and the tumor microenvironment (TME). MiRNAs have context-dependent actions and can promote or suppress angiogenesis dependent on the type of cancer. On the one hand, miRNAs downregulate anti-angiogenic targets and lead to angiogenesis induction. Tumor suppressor miRNAs, on the other hand, enhance anti-angiogenic response by targeting pro-angiogenic factors. Understanding the interaction between these miRNAs and their target mRNAs will help to unravel molecular mechanisms involved in CRC progression. The aim of this article is to review the current literature on angioregulatory miRNAs in CRC.
\end{abstract}

Keywords: colorectal cancer 1; angiogenesis 2; microRNA 3

\section{Introduction}

Angiogenesis is a coordinated multi-step process, which serves to fulfill nutrient and oxygen demand of normal and cancerous tissues and can be controlled by microRNAs (miRNAs) at multiple levels. MiRNAs are small non-coding RNAs comprised of 18-25 bases and they post-transcriptionally regulate gene expression including the expression of oncogenes and tumor suppressor genes in cancer [1-3]. MiRNAs bind to the $3^{\prime}$-untranslated regions (3'-UTRs) of target mRNAs and repress translation or cause transcript degradation. Functional studies by miRNA overexpression or inhibition have revealed prominent roles of miRNAs in various types of cancer including colorectal cancer (CRC). In addition to their pivotal role in tumor cell migration and invasion, miRNAs can modulate the expression of angiogenic or anti-angiogenic factors. Imbalance between these factors leads to dysregulation of angiogenesis and aberrant vascular architecture in cancer [4]. Endothelial cells (ECs) are a major component of the (tumor microenvironment) TME and formation of neo-vessels is critical in CRC growth and metastasis [5]. The metastatic and angiogenic potential of CRC cells depends on interaction with ECs through various signals including the transfer of molecules via exosomes. Exosomes are a type of extracellular vesicles that have a size of 30-100 nm and contain growth factors, lipids, and non-coding RNAs, which are involved in the communication between tumor and stroma cells [6]. Exosomes are taken up by target cells through different pathways 
such as cell membrane fusion and receptor-mediated endocytosis [7]. Exosomal angio-miRNAs and other angiogenesis-related factors released from CRC cells can transport angiogenic signals to ECs. Multiple signaling molecules and pathways such as hypoxia-inducible factor $1 \alpha$ (HIF $1 \alpha)$, vascular endothelial growth factor (VEGF)/vascular endothelial growth factor receptor (VEGFR), phosphoinositide 3-kinases (PI3K)/protein kinase B (AKT)/mammalian target of rapamycin (mTOR), transforming growth factor $\beta$ (TGF $\beta$ ), extracellular-signal-regulated kinase (ERK) and WNT/ $\beta$-catenin contribute to CRC angiogenesis. Interestingly, miRNAs are crucial regulators of these factors and pathways. Moreover, anti-angiogenic therapies have improved the survival of CRC patients. Therefore, investigation of angiogenesis-related miRNAs could help to find effective non-coding RNA-based drugs and novel diagnostic, prognostic, or predictive biomarkers. For example, anti-miR-21 could bind to pri-miR-30 and inhibit tubulogenesis in CRC [8]. In this review, we discuss the current state of research on the roles of angioregulatory miRNAs in CRC.

\section{MiRNAs Regulate Physiological and Pathological Angiogenesis}

Angiogenesis normally occurs during physiological processes like embryonic development, wound healing, and the menstrual cycle. Embryonic stem cell differentiation to endothelial progenitor cells and ECs is regulated by angio-miRs during embryonic development [9] and also placenta angiogenesis in pregnancy can be modulated by miRNAs [10]. MiR-17, -20 and $-20 \mathrm{~b}$ contribute to placenta angiogenesis through targeting EPHB4 and ephrin-B2 and their differential expression in preeclampsia compared with normal pregnancies suggests angioregulatory roles of these miRNAs in placenta pathogenesis [11]. It has been reported that recurrent miscarriage is linked to aberrant expression of miR-16 in villi and decidua in addition to peripheral mononuclear cells [12,13]. Neoangiogenesis is a critical step in wound healing by providing nutrient and oxygen supply at the wound site. Angioregulatory functions of miR-148b, miR-615-5p, miR-200b, miR-27b, miR-21, and miR-199a-5p in wound healing have been investigated in several studies (Table 1).

MiRNAs also regulate endometrium function and differentiation into the receptive state in the menstrual cycle [14]. Extracellular miRNAs can be involved in endometrial-peritoneal interactions which modulate angiogenesis in endometriosis. An in vitro study demonstrated that peritoneal fluid treatment of endometrial cell cultures resulted in decreased expression of miR-16, -17-5p, -20a, -125a, -221, and -222 which led to increased VEGFA expression [15].

Table 1. MiRNAs involved in regulation of angiogenesis during wound healing.

\begin{tabular}{ccc}
\hline MiRNA & Functions & Ref. \\
\hline MiR-21 & Exosomal miR-21 promotes angiogenesis through PTEN and SPRY1 suppression & {$[16,17]$} \\
\hline MiR-26a & Impairs angiogenesis by targeting SMAD1 & {$[18]$} \\
\hline MiR-27b & Facilitates angiogenesis by downregulation of THBS1, Sema6A and p66Shc & {$[19]$} \\
\hline MiR-92a & Angiogenesis in fracture healing could increase by miR-92a inhibition & {$[20]$} \\
\hline MiR-125a & Enhances angiogenesis by DLL4 repression & {$[21]$} \\
\hline MiR-126 & Blood vessel formation through VEGF and bFGF signaling & {$[22]$} \\
\hline MiR-135a-3p & Inhibits angiogenesis by targeting of VEGF-HIP1-p38K signaling & {$[23]$} \\
\hline MiR-148b & Promotes wound healing by TGF $\beta$ signaling regulation & {$[24]$} \\
\hline MiR-199a-5p & Suppresses angiogenesis by targeting of the Ets-1-MMP1 pathway & {$[25]$} \\
\hline MiR-615-5p & Suppresses angiogenesis by regulation of the VEGF-AKT/eNOS signaling pathway & {$[26]$} \\
\hline
\end{tabular}

\section{CRC Progression and Metastasis Are Regulated by MiRNA-Mediated Crosstalk between Tumor Cells and the TME}

Endothelial cells, fibroblasts, tumor-associated macrophages (TAMs), pericytes, and lymphocytes contribute to tumorigenesis through various activities such as angiogenesis dysregulation, immune 
evasion, growth factor overexpression, and extracellular matrix modification. Cancer-associated fibroblasts (CAFs) are major players in the TME and contribute to tumor-stroma interactions. Bhome et al. have shown miR-329, miR-181a, miR-199b, miR-382, miR-215, and miR-21 to be enriched in CAF-derived exosomes in CRC [27]; Moreover, they confirmed miR-21 transfer from CAFs to CRC cells which led to increased tumor cell invasion and metastasis. TAMs are another crucial component of the tumor stroma. These cells can have a dual effect on tumorigenesis [28]. M2 macrophagederived exosomes containing miR-21-5p and miR-155-5p were shown to target brahma-related gene 1 (BRG1) when transmitted to CRC cells and thereby inhibited metastasis [29]. Oncogenic role of BRG1 through Wnt3a upregulation have been demonstrated in CRC both in vitro and in vivo [30]. Increased expression of BRG1 is correlated with epithelial-mesenchymal transition (EMT) marker SNAI and associated with poor prognosis in CRC patients [31]. TAM also regulate STAT3-mediated suppression of miR-506-3p in CRC [32]. Another miRNA which is involved in CRC and TME interplay is miR-506-3p. FoxQ1 inhibition via miR-506-3p and subsequent CCL2 upregulation can promote circulating tumor cell (CTC)-mediated tumor metastasis in CRC patients [32]. The angiogenic switch of CRC involves VEGF secretion from cancer cells under hypoxic conditions which triggers angiogenesis via VEGFR expressed on ECs. MiRNAs were shown to suppress VEGF expression in tumor cells and VEGFR expression in ECs $[33,34]$. Thus, on the one hand, miRNAs can regulate communication between tumor cells and different components of the TME by modulating the expression of growth factors or their receptors. Angioregulatory miRNAs can be transferred to various cells in the tumor niche via exosomes and shuttling of miRNAs between tumor cells and cells of the TME is an important aspect in cellular communication (Figure 1). Importantly, exosomal miRNAs can be detected in body fluids and serve as non-invasive biomarkers in CRC [35]. Several putative angio-miRs were investigated in CRC via anti-miRNA oligonucleotides or overexpression of miRNAs and the respective studies will be discussed below (Tables 2 and 3).

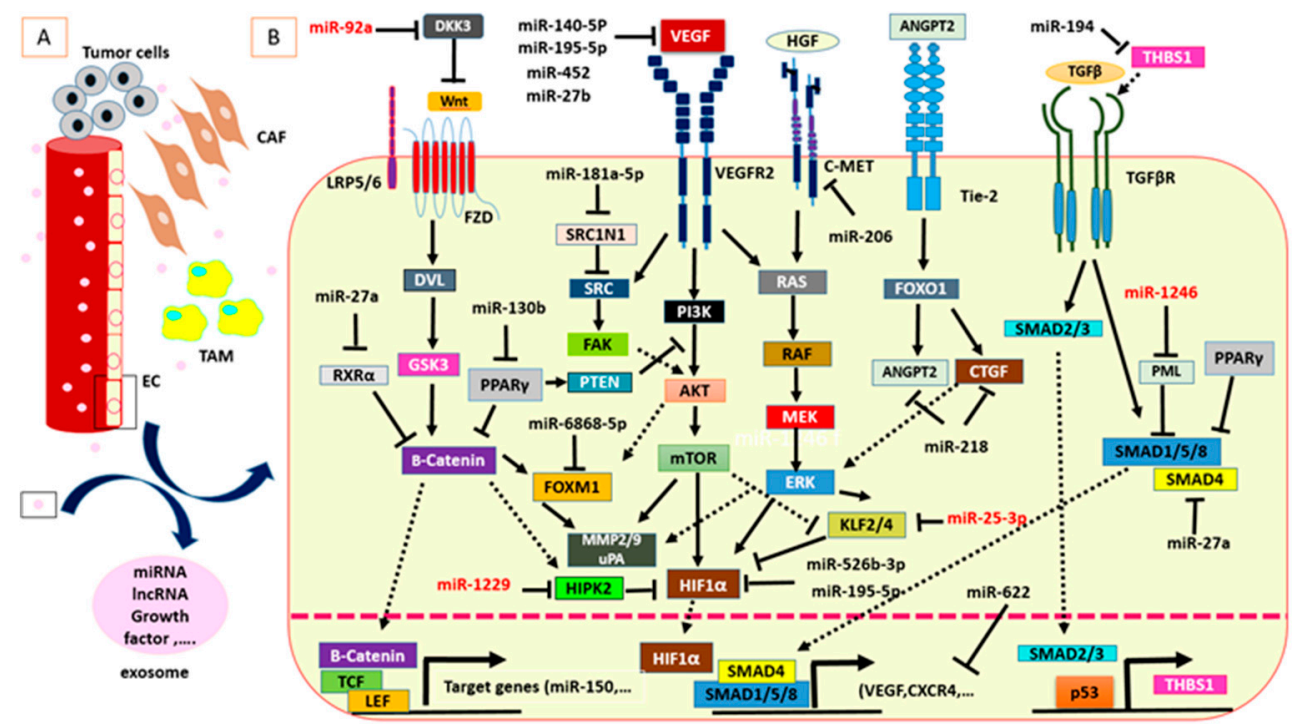

Figure 1. MiRNAs are critical mediators in CRC angiogenesis. (A) Communication between CRC cells and TME components such as ECs could be mediated by exosomes. (B) Intracellular and exosome-derived miRNAs are involved in important molecular pathways of CRC angiogenesis. Exosome-derived miRNAs are shown in red color. 
Table 2. Angioregulatory miRNAs in CRC.

\begin{tabular}{|c|c|c|}
\hline Angiogenic MiRNAs & Target Genes or Molecular Pathways Involved in Angiogenesis & Ref. \\
\hline MiR-92a & DKK3 and claudin-11 & [36] \\
\hline MiR-1246 & PML inhibition and SMAD 1/5/8 signaling activation & [37] \\
\hline MiR-1229 & HIPK2 & [38] \\
\hline MiR-25-3p & KLF2 and KLF4 & [39] \\
\hline MiR-181a-5p & SRC/VEGF signaling & [40] \\
\hline MiR-194 & THBS1 & [41] \\
\hline MiR-130b & PPAR $\gamma$ & [42] \\
\hline MiR-27a & SMAD4 & [43] \\
\hline \multicolumn{3}{|c|}{ Antiangiogenic MiRNAs } \\
\hline MiR-27b & VEGFC & [33] \\
\hline MiR-206 & Met/ERK/Elk-1/HIF-1 $\alpha /$ VEGF-A pathway inhibition & {$[44]$} \\
\hline MiR-126 & VEGFA & [45] \\
\hline MiR-143 & PI3K/AKT/HIF-1/VEGF & [46] \\
\hline MiR-1249 & VEGFA and HMGA2 & [47] \\
\hline MiR-590-5p & NF90 & {$[48]$} \\
\hline MiR-218 & CTGF, VEGFA and ANGPT2 & [49] \\
\hline MiR-6868-5p & FOXM1 & {$[50]$} \\
\hline MiR-107 & HIF-1 $\beta$ & [51] \\
\hline MiR-150-5p & ZFAS1 and VEGFA & {$[52]$} \\
\hline MiR-125a-3p \& 5p & FUT5 and FUT6/ VEGFA & {$[53,54]$} \\
\hline MiR-140-5p & VEGFA & {$[55]$} \\
\hline MiR-145 & P70S6K1 & [56] \\
\hline MiR-195-5p & VEGFA, DLL4, ENG, HIF- $1 \alpha$ and HIF- $1 \beta$ & [57] \\
\hline MiR-622 & CXCR4 and VEGF & [58] \\
\hline MiR-452 & SRC/BRAF/MAPK signaling pathway inhibition & [59] \\
\hline
\end{tabular}

Table 3. CRC related angio-miRNAs in other types of cancer and/or disorders (excluding CRC).

\begin{tabular}{|c|c|c|c|c|}
\hline MiRNAs & Cancer and/or Other Disorders & Angiogenic/Anti-Angiogenic & $\begin{array}{l}\text { Target Genes or Molecular Pathways } \\
\text { Involved in Angiogenesis }\end{array}$ & Ref. \\
\hline MiR-92a & $\begin{array}{l}\text { 1. Vascular injury } \\
\text { 2. Mouse hind-limb ischemia } \\
\text { model }\end{array}$ & Antiangiogenic & $\begin{array}{l}\text { 1. JNK and ERK1/2 pathway is activated } \\
\text { following by miR-92a suppression. } \\
\text { 2. Integrin subunit a5 (ITGA5) }\end{array}$ & {$[60,61]$} \\
\hline MiR-1246 & Corneal neovascularization & Antiangiogenic & Angiotensin-converting enzyme (ACE) & [62] \\
\hline MiR-181a-5p & Chondrosarcoma & Angiogenic & $\begin{array}{l}\text { RGS16 (CXC chemokine receptor } 4 \text { (CXCR4) } \\
\text { signaling) }\end{array}$ & [63] \\
\hline MiR-206 & $\begin{array}{l}\text { 1. Breast cancer } \\
\text { 2. Non-small cell lung cancer } \\
\text { 3. Laryngeal cancer }\end{array}$ & Antiangiogenic & $\begin{array}{l}\text { 1. VEGF, MAPK3 and SOX9 } \\
\text { 2. c-Met/PI3K/AKT/mTOR pathway } \\
\text { 14-3-3乙/STAT3/HIF-1 } \alpha / \text { VEGF signaling } \\
\text { 3. VEGF }\end{array}$ & [65-68] \\
\hline MiR-126 & $\begin{array}{l}\text { 1. Gastric cancer } \\
\text { 2. Oral cancer } \\
\text { 3. Breast cancer } \\
\text { 4. Spinal cord injury } \\
\text { 5. Ischemic mouse brain } \\
\text { 6. Arteriosclerosis }\end{array}$ & Antiangiogenic & $\begin{array}{l}\text { 1 \& 2: VEGF-A } \\
\text { 3. VEGF/PI3K/AKT signaling pathway } \\
\text { 4. SPRED1, PIK3R2 \& VCAM1 } \\
\text { 5. PTPN9 suppression and AKT and ERK } \\
\text { signaling pathways activation } \\
\text { 6. PI3K/AKT JAK2/STAT5 signaling pathway } \\
\text { suppression following by curcumin treatment }\end{array}$ & [69-75] \\
\hline MiR-140-5p & $\begin{array}{l}\text { 1. Breast cancer } \\
\text { 2. Glioma } \\
\text { 3. Larynx carcinoma } \\
\text { 4. mouse model of Retinopathy }\end{array}$ & Antiangiogenic & $\begin{array}{l}\text { 1. VEGF } \\
\text { 2. VEGFA/MMP } \\
\text { 2 signaling } \\
\text { 3. VEGFA } \\
\text { 4. TMOD3 }\end{array}$ & {$[76-79]$} \\
\hline
\end{tabular}


Table 3. Cont

\begin{tabular}{|c|c|c|c|c|}
\hline MiRNAs & Cancer and/or Other Disorders & Angiogenic/Anti-Angiogenic & $\begin{array}{l}\text { Target Genes or Molecular Pathways } \\
\text { Involved in Angiogenesis }\end{array}$ & Ref. \\
\hline MiR-143/miR-145 & Lung cancer & Antiangiogenic & Camk1d & [80] \\
\hline MiR-145 & $\begin{array}{l}\text { 1. Breast cancer } \\
\text { 2. Neuroblastoma }\end{array}$ & Antiangiogenic & $\begin{array}{l}\text { 1. VEGF and N-RAS } \\
\text { 2. HIF- } 2 \alpha\end{array}$ & {$[81,82]$} \\
\hline MiR-590-5p & Oral squamous cell carcinoma & Angiogenic & CD44 and VE-cadherin & [83] \\
\hline MiR-107 & $\begin{array}{l}\text { 1. Glioma } \\
\text { 2. Liver cancer } \\
\text { 3.Ischemia-induced cerebral } \\
\text { injury }\end{array}$ & $\begin{array}{l}\text { 1\& 2. Antiangiogenic } \\
\text { 3. Angiogenic }\end{array}$ & $\begin{array}{l}\text { 1. VEGF } \\
\text { 2. HULC mediated E2F1-SPHK1 signaling } \\
\text { 3. Dicer-1 }\end{array}$ & [84-86] \\
\hline MiR-526b & Breast Cancer & Angiogenic & $\begin{array}{l}\text { NFKB pathway } \\
\text { PI3K/Akt signaling }\end{array}$ & [87] \\
\hline MiR-150-5p & $\begin{array}{l}\text { 1. Paclitaxel-resistant ovarian } \\
\text { cancer } \\
\text { 2. Rheumatoid arthritis }\end{array}$ & Antiangiogenic & $\begin{array}{l}\text { 1. Notch3 signaling } \\
\text { 2. MMP14 and VEGF }\end{array}$ & {$[88,89]$} \\
\hline MiR-195-5p & $\begin{array}{l}\text { 1. Squamous cell lung cancer } \\
\text { 2. Ovarian cancer } \\
\text { 3. Hepatocellular carcinoma } \\
\text { 4. Prostate cancer }\end{array}$ & Antiangiogenic & $\begin{array}{l}\text { 1. VEGF } \\
\text { 2. PSAT1-dependent GSK } 3 \beta / \beta \text {-catenin } \\
\text { signaling pathway } \\
\text { 3. VEGF, VAV2, and CDC42 } \\
\text { 4. PRR11 }\end{array}$ & [94-97] \\
\hline MiR-218 & $\begin{array}{l}\text { 1. Gastric cancer } \\
\text { 2. Prostate cancer }\end{array}$ & Angiogenic & $\begin{array}{l}\text { 1. ROBO1 } \\
\text { 2. RICTOR }\end{array}$ & {$[98,99]$} \\
\hline MiR-452 & Breast cancer & Antiangiogenic & SNAI2 & [100] \\
\hline
\end{tabular}

\section{Pro-Angiogenic MiRNAs in CRC}

MiR-92a: MiR-92a is a member of the miR-17-92 cluster which is a prominent oncomiR cluster in CRC. MiR-17 92 promotes CRC angiogenesis via targeting transforming growth factor $\beta$ type II receptor (TGF $\beta R 2), H I F 1 \alpha$, and VEGFA [101]. A miR-92a/KLF4/p21 axis facilitates CRC cell proliferation and migration [102]. Exosome-mediated transfer of miR-92a from colon cancer cells to endothelial cells leads to angiogenesis induction through downregulation of Dickkopf-3 (DKK3) and claudin-11 [36]. Several studies have shown that DKK3 has a diverse function in tumor angiogenesis and oncogenesis [103-106]. Busceti et al. have indicated an angio-promoting role of DKK3 via VEGF upregulation [107]. DKK3 upregulation in CRC tissue compared to normal adjacent tissue correlated with increased microvessel formation [108]. DKK3 interaction with $\beta 2$-microglobulin $(\beta 2 \mathrm{M})$ inhibits VEGFR-2/Akt/mTOR signaling activation in ovarian cancer and inhibits angiogenesis [109]. DKK3 also modulates the Wnt/ $\beta$-catenin signaling pathway and could be a diagnostic and prognostic biomarker in the serum of CRC patients [110]. Claudin-11 belongs to the claudin transmembrane protein family which is required for the formation of endothelial cell tight junctions. Tight junctions are involved in extravasation and angiogenesis [111]. Claudin-11 hyper-methylation is linked to colon cancer progression and metastasis [112].

MiR-1246: miR-1246 is a highly expressed oncomiR in CRC tissue and serum compared to controls and was identified as a novel CRC biomarker $[113,114]$. MiR-1246 enhances tumor growth, invasion, and metastasis and is involved in chemoresistance and self-renewal ability, a characteristic feature of cancer stem cells in CRC $[115,116]$. Pri-miR-1246 methylation by METTL3 (methyltransferase) upregulation can facilitate miR-1246 maturation and subsequently MAPK signaling activation in CRC [117]. Exosome-derived miR-1246 can be taken up by HUVECs and promotes angiogenesis through promyelocytic leukemia protein $(P M L)$ inhibition and SMAD 1/5/8 signaling activation [37]. A number of reports have demonstrated a significant role of SMAD signaling in angiogenesis $[118,119]$. TGF- $\beta / S M A D$ mediated angiogenesis could be further enhanced by cooperation with insulin in EC [120]. PML could exert its antiangiogenic roles in IFN- $\alpha$-dependent manner. In addition, PML negatively regulates angiogenesis via suppression of mTOR-HIF1 $\alpha$ [121]. HIF- $1 \alpha$ is a key player in hypoxic signaling and tumor neovascularization. Sorafenib is a multi-targeted tyrosine kinase inhibitor 
which inhibits CRC angiogenesis and proliferation [122]. A panel of miRNAs including miR-1246 were shown to have decreased expression in response to Sorafenib treatment in the Caco-2 cell line [123].

MiR-1229: miR-1229 is part of a panel of 5 serum miRNAs that provides superior specificity and sensitivity for early detection of CRC and could be applied to distinguish CRC from colorectal adenomas and healthy individuals [124]. CRC-derived exosomal miR-1229 is elevated in the serum of patients and leads to tube formation in HUVECs in vitro through HIPK2 inhibition and subsequent VEGF upregulation [38]. An inverse association between HIPK2 and VEGF expression supports an antiangiogenic activity of HIPK2 [125]. Moreover, HIPK2 activates p53 and inhibits tumorigenesis [126].

MiR-25-3p: MiR-25 has a contradictory role in CRC development and its tumor suppressive or oncogenic function in CRC has been demonstrated in several conflicting studies [127,128]. Exosomal miR-25-3p is involved in VEGF signaling pathway activation and enhanced vascular permeability through suppression of KLF2 and KLF4 (Krüppel-like factor) in HUVECs [39]. The KLF2/HIF-1 $\alpha /$ Notch-1 signaling axis suppresses CRC proliferation and activates apoptosis [129]. KLF4 has a tumor suppressor function and low expression is associated with poor survival of CRC patients [130].

MiR-181a-5p: miRNA-profiling analysis revealed significant overexpression of miR-181a in liver metastatic compared with non-metastatic CRC. Moreover, in vitro studies have shown that lenti-miR-181a targets Wnt inhibitory factor-1 (WIF-1) and can boost tumor progression, metastasis, and EMT [40]. MiR-181a-5p promotes angiogenesis through SRC/VEGF signaling. SRC1N1 as a direct target of miR-181a-5p inhibits SRC and subsequently suppresses the VEGF pathway [40]. However, in contradiction to its angiogenic role, miR-181a-5p was also shown to suppress MMP-14 and reduce angiogenesis in CRC [131]. Several studies have confirmed an angiogenic function of MMP-14. It mediated corneal angiogenesis through VEGFR1 cleavage and was upregulated in proliferative diabetic retinopathy $[132,133]$. Another report showed that MMP-14 promotes invasiveness and angiogenesis through VEGF and PTTG [134]. Decreased expression of miR-181a after anti-EGFR treatment in CRC suggests an angiogenic activity of this miRNA.

MiR-194: miR-194 contribution to carcinogenesis has been studied in various types of cancer but its role in CRC remains controversial. MiR-194 is involved in EMT induction and invasion in CRC cell lines [135]; nevertheless, its downregulation in CRC tissue compared to adjacent non-cancerous tissue and its association with inhibition of cell proliferation via regulation of the MAP4K4/c-Jun/MDM2 signaling pathway indicate tumor suppressive features of miR-194 [136]. It has been reported that the miR-194 promoter has a binding site for Snail which leads to miR-194 downregulation and THBS1 upregulation in snail-mediated EMT in HT-29 cells [137]. THBS1 (thrombospondin 1) is an intrinsic inhibitor of angiogenesis which also has a suppressive effect on CRC proliferation and migration. It can be regulated post-transcriptionally by miR-194 in addition to being induced by p53 suggesting that the P53/THBS1axis is regulated by miR-194 in CRC [41].

MiR-27a: miR-27a promotes CRC proliferation, migration, and invasion by downregulation of $R X R \alpha$ [138]. RXR $\alpha$ interacts with $\beta$-catenin and suppresses the $W n t / \beta$-catenin signaling pathway [139]. Immunogenic cell death induced by chemotherapeutic drugs such as mitoxantrone and oxaliplatin can be impaired by miR-27a overexpression in CRC. MiR-27a directly targets calreticulin, a mediator for eliciting immunogenic cell death [140]. Conditioned media from high miR-27a expressing CRC cell lines promote angiogenesis in HUVECs; moreover, the angiogenic potential of miR-27a has been demonstrated in a mouse xenograft model of CRC [141]. Increased miR-27a expression in human lymphatic endothelial cells (HLECs) stimulates lymphangiogenesis under co-culture with colon cancer cells [43].

MiR-130b: miR-130b expression is notably elevated in CRC and leads to poor prognosis in a PPAR $\gamma$-dependent manner [42]. However, miR-130b may also have a tumor suppressor function in CRC by attenuating migration and invasion through targeting $\beta 1$-integrin [142]; hence, the exact role of miR-130b in CRC is still debatable. PPAR $\gamma$ suppression by miR-130b contributes to increased VEGF expression, suggesting a pro-angiogenic function of miR-130b in CRC [42]. 


\section{Anti-Angiogenic MiRNAs in CRC}

MiR-27b: miR-27b expression is downregulated in CRC tissue and plays tumor-suppressive role through Rab3D inhibition [143]. VEGFC suppression by miR-27b demonstrates antiangiogenic function of miR-27b in CRC [33]. VEGFC is one of the VEGF isoforms that regulates lymphangiogenesis [144]. VEGFC activates p38MAPK and NOTCH1 which leads to angiogenesis [145]. VEGFC upregulation is involved in CRC immune evasion and tumor growth [146,147].

MiR-206: Prognostic value of miR-206 has been shown in CRC patients. Low expression of miR-206 in cancerous tissue is linked to poor overall survival of patients [148] The anti-tumor effect of miR-206 in CRC is mediated via targeting various genes such as transmembrane 4 L6 family member 1 (TM4SF1) and VEGF [149]. NOTCH3 signaling suppression by miR-206 is associated with apoptosis induction, reduced migration and metastasis in CRC [150]. Furthermore, low expression of miR-206 resulting in higher BCL-2 expression increased 5-fluorouracil (5-FU)-resistance in colon cancer [151]. It has been demonstrated that CCL19 can inhibit angiogenesis in CRC by miR-206 upregulation which subsequently leads to negative regulation of the Met/ERK/Elk-1/HIF-1 $\alpha /$ VEGF-A pathway [44].

MiR-126: Reduced expression of miR-126 has been observed in metastatic CRC and correlated with poor clinical outcome [152]. MiR-126 suppresses colon cancer migration, invasion, and proliferation via targeting various targets such as CXCR4, IRS1, SLC75A, and TOM1 [153,154]. Multiple signaling pathways are negatively regulated by miR-126 including RhoA/ROCK, AKT, and ERK1/2 [155-157]. Epigenetic suppression of miR-126 leads to VEGF-mediated angiogenesis [45]. However, Hansen et al. have indicated that miR-126 overexpression is correlated with high level expression of VEGFR-2 and consequently CRC neo-angiogenesis [158]. Circulating miR-126 could be a predictive biomarker in metastatic CRC for treatment with the monoclonal anti-VEGF antibody Bevacizumab since [159] poor patient response to Bevacizumab was associated with increased levels of extracellular miR-126 in plasma.

MiR-143: Increased circulating serum miR-143 is a predictive biomarker for favorable neo-adjuvant therapy response in advanced rectal cancer [160]. MiR-143 downregulation is correlated with poor prognosis and promotes oxaliplatin-based chemotherapy response through downregulation of (insulin-like growth factor-I receptor) IGR-IR and superoxide dismutase 1 (SOD1) [46,161]. The role of IGR-IR in angiogenesis is in association with PI3K/AKT. Therefore, the PI3K/AKT/HIF-1/VEGF pathway is a possible target in miR-143 anti-angiogenic function [46].

MiR-1249: The miR-1249 promoter has a p53 binding site and its expression is induced by P53 [47]. Chen et al. have shown elevated expression of miR-1249 is associated with decreased CRC cell metastasis and angiogenesis by blocking of VEGFA and high mobility group AT-hook 2 (HMGA2) [47]; Moreover, by in vivo angiogenesis assays, they have demonstrated that an inverse correlation between MiR-1249 and CD31 which is linked to anti-angiogenic functions of miR-1249. The EC marker CD31 participates in the intercellular junction of ECs [162].

MiR-590-5p: Zhang, G.-J. et al. have reported that miR-590 upregulation predicts poor prognosis for CRC patients [163]. In addition, they have shown that PTEN expression is suppressed by miR-590 in CRC suggesting an oncogenic role of this miRNA via the PTEN/PI3K/Akt/mTOR pathway. Hypoxia-regulated miR-590-5p dysregulation in CRC is associated with tumor metastasis by depleting RECK (reversion-inducing cysteine-rich protein with Kazal motifs) levels [164]. RECK regulates angiogenesis through MMP modulation [165]. MiR-590-5p is involved in VEGF- dependent angiogenesis by NF90 (targeting nuclear factor 90) suppression [48]. NF90 promotes angiogenesis by induction of HIF-1 $\alpha$ and VEGF expression through the PI3K/AKT signaling pathway [166].

MiR-218: Several studies have shown downregulation and anti-tumoral functions of miR-218 in CRC samples and cell lines. MiR-218 negatively regulates EMT and angiogenesis. Silencing the expression of CTGF, VEGFA and ANGPT2 after miR-218 transfection into CRC cell lines verified the anti-angiogenic role of miR-218 [49]. The angiogenic potential of connective tissue growth factor (CTGF) and ANGPT2 in association with miRNAs has been shown in various studies. MiR-210 
upregulation by CTGF mediates VEGF expression in osteoarthritis [167]. CTGF decreased miR-543 and leads to angiogenesis by ANGPT2 upregulation in osteosarcoma [168].

MiR-6868-5p: Decreased expression of miR-6868-5p is associated with tumor-mediated angiogenesis in CRC patients [50]. MiR-6868-5p suppresses forkhead box M1 (FOXM1) which is an oncogene and angiogenesis mediator. Moreover, there is a negative feedback loop between miR-6868-5p expression and FOXM1. MiR-6868-5p inhibits IL-8 indirectly through FOXM1 suppression [50]. FOXM1 has been demonstrated to crosstalk with the TGF- $\beta$ and Wnt pathways and its expression is correlated with MMP-2, MMP-9, VEGF, and urokinase-type plasminogen activator (uPA), and hence, FOXM1 can modulate angiogenesis, migration, and proliferation of tumor cells $[169,170]$.

MiR-107: Studies on miR-107 functions in CRC show conflicting results. Transferrin receptor 1 (TFR1) is a direct target of miR-107 and its overexpression promotes proliferation and invasion of CRC cell lines [171]. Although, miR-107 expression is regulated by p53 in CRC, this regulation is not in accordance with tumor suppressive roles of miR-107 [172]. The miR-103/107 family sustains stemness of CRC cells by hyperactivation of Wnt/ $\beta$-catenin signaling [173]. The predictive value of miR-107 has been demonstrated in metastatic CRC patients in response to chemotherapy [174]. An inverse correlation between miR-107 and hypoxia-inducible factor-1 $\beta$ (HIF-1 $\beta$ ) suggests an anti-angiogenic function of miR-107 in CRC [51]. HIF-1 $\beta$ suppression by p53-responsive miR-107 impairs hypoxic signaling and angiogenesis in CRC [51].

MiR-526b-3p: Although angiogenic potential of miR-526b-3p has not been investigated in CRC but it negatively regulates HIF-1 $\alpha$ therefore, this reverse relationship might be involved in angiogenesis $[175,176]$. We have performed a bioinformatics analysis by DIANA-miRPath v3 [177] for finding predicted angiogenesis-related signaling pathways that could be regulated by miR-526b-3p. This suggested that miR-526b-3p blocks targets such as VEGFA and PTEN in the MAPK and mTOR signaling pathways (data not shown).

MiR-150-5p: Reports regarding miR-150-5p function in CRC show contradictory results. Decreased expression of miR-150-5p was proposed as a predictive biomarker for poor adjuvant chemotherapy response in CRC patients [178]. Moreover, low serum levels of exosomal miR-150-5p and miR-99b-5p can distinguish CRC patients from healthy individuals [179]. Despite these reports, Liu and Wang et al. have introduced miR-150-5p as an oncomiR in CRC progression [180]. They have shown that p53 is targeted by miR-150-5p in CRC. MiR-150-5p expression was stimulated by the Wnt/ $\beta$-catenin signaling pathway and, furthermore, miR-150-5p could repress cAMP response element-binding protein (CREB) expression which causes EMT in colon cancer [181]. Several studies have shown long non-coding RNA (lncRNA) and miRNA interactions in cancer development. ZNFX1 antisense RNA1 (ZFAS1) is a lncRNA which acts as miRNA sponge and can indirectly regulate miR-150 targets (ZFAS1 and $V E G F A$ ) [52]. Indeed, the angioinhibitory function of miR-150-5p is mediated by VEGFA suppression which subsequently leads to tumor growth inhibition in CRC.

MiR-125a-3p \& 5p: Upregulation of exosomal miR-125a-3p in CRC patients' plasma can be a useful biomarker in early detection of CRC [182]. MiR-125a-3p inhibits angiogenesis in CRC by targeting fucosyltransferases (FUT5 and FUT6); FUT contributes to CRC progression via the PI3K/Akt signaling pathway [53]. FUTs are endoplasmic reticulum and Golgi resident membrane-bound proteins which regulate several signaling factors such as VEGFR and the PI3K/AKT signaling pathway [183]. Serum fucosylation profiles could be valuable biomarkers in different types of cancer [183]. MiR-125a-5p tumor suppressive functions in CRC have been demonstrated in several studies. TAZ is a direct target of miR-125a-5p and its overexpression reverses CRC cell invasion and migration mediated by miR-125a-5p [184]. Apoptosis induction via targeting of BCL2, BCL2L12, and Mcl-1 in colon cancer cells by miR-125a-5p is another aspect of the tumor suppressive role of this miRNA [185]. MiR-125a-5p also suppresses tube formation of HUVECs by targeting VEGFA [54].

MiR-140-5p: MiR-140-5p is involved in EMT activation and maintenance of cancer stem cell characteristics in CRC through SMAD2 downregulation downstream of TGF $\beta$ signaling [186]. MiR-140-5p and lncRNA cancer susceptibility 19 (CASC19) interaction can abolish the oncogenic role 
of CASC19 in CRC [187]. MiR-140-5p downregulation in CRC tissue correlated with TNM stage and poor overall survival of CRC patients $[188,189]$. Zhang et al. have shown VEGFA as a valid direct target of miR-140-5p in CRC; however, tube formation ability was not evaluated in this study [55].

MiR-145: MiR-145 is recognized as a tumor-suppressive miRNA in CRC. MiR-145 inhibits colon cancer cell migration and invasion through post-transcriptional suppression of p21-activated kinase 4 (PAK4) [190]. PAK4 acts at the cross-point between MAPK and Wnt/ $\beta$-catenin signaling and is essential for cell migratory ability and survival [191]. Interaction between oncogenic colon cancer-associated transcript-2 (CCAT2) lncRNA and miR-145 leads to decreased maturation of pre-miR-145 [192]. Glioma-derived exosomal CCAT2 transfer to ECs and induction of VEGF expression has been reported [193]. The 70kDa ribosomal S6 kinase (P70S6K1) is a direct target of miR-145 and exerts its pro-angiogenic function through VEGF and HIF-1 $\alpha$ expression [56,194]. Another study showed a contradictory role of miR-145 in angiogenic response. CRC-derived exosomes containing miR-145 could transfer information to TAMs and induce M2 polarization of TAMs which overexpress VEGF and participate in tumor angiogenesis [195].

MiR-195-5p: MiR-195-5p is downregulated in CRC tissue and is associated with chemotherapy sensitivity in CRC by targeting glycerophosphodiester phosphodiesterase domain containing 5 (GDPD5) repression [196,197]. Downregulation of WNT3A by miR-195-5p inhibits CRC cell migration and proliferation [198]. WNT3A overexpression exerts its pro-angiogenic function in CRC cell lines by VEGFR2 and VE-cadherin upregulation [199]. DKK1 is a Wnt/ $\beta$-catenin antagonist that can repress WNT3A activity and serves as tumor-suppressive factor in CRC [200]. Another study showed that miR-195-5p downregulates several angiogenic genes such as VEGFA, DLL4, ENG, HIF-1 $\alpha$, and HIF-1 $\beta$ in CRC [57].

MiR-622: MiR-622 is downregulated in CRC and suppresses migration, invasion, and proliferation of cancer cells by targeting various targets such as dual-specificity tyrosine phosphorylation-regulated kinase 2 (DYRK2) and Kirsten rat sarcoma (K-Ras) [201]. MiR-622 expression can be induced by radiotherapy and causes radioresistance through retinoblastoma protein $(R b)$ inhibition in CRC [202]. Fang et al. have reported that miR-622 negatively regulates angiogenesis both in vitro and in vivo by (C-X-C chemokine receptor 4) CXCR4 and VEGF suppression [58]. HUVEC treatment with CRC cell line-derived conditioned medium suppresses tube formation and migration by CXCR4 inhibition; moreover, CXCR4 is upregulated due to hypoxia in CRC and CXCR4/VEGF/HIF1 $\alpha$ signaling has a correlation with the TNM stage $[203,204]$.

MiR-452: MiR-452 activates Wnt/ $\beta$-catenin through GSK3 $\beta$ suppression and might evoke cell cycle progression in CRC by blocking cyclin-dependent kinase inhibitor 1B (CDKN1B) [205]. Mo et al. have demonstrated that miR-452 targets VEGF and inhibits tumor angiogenesis [59]. Furthermore, they have shown that miR-452-mediated suppression of VEGF resulted in SRC/BRAF/MAPK signaling pathway inhibition.

\section{Conclusions}

Angiogenesis is a key process in physiological and pathological conditions and is controlled by various angiogenic and anti-angiogenic factors. The imbalance between these factors leads to dysregulation of angiogenesis during development of tumors including CRC. MiRNAs are important mediators in this context and, consequently, have emerged as novel diagnostic, prognostic, and predictive biomarkers in CRC. MiRNAs can target angiogenesis-related oncogenic or tumor suppressor mRNAs in different signaling pathways in either tumor cells or cells of the TME and thereby exert angiogenic or anti-angiogenic functions. Moreover, exosomal miRNAs can shuttle between CRC cells and the TME and transduce angiogenesis-regulating signals between different cellular components to either boost or impair tumor progression. Altogether, understanding the multiple roles of miRNAs in CRC angiogenesis could help to identify new biomarkers and improve miRNA-based antiangiogenic therapies. 
Author Contributions: Conceptualization and writing original draft preparation, M.H.S.; Review and editing equally, M.G. and H.K.N.; Supervision and data curation, R.A. and Z.W.; Editing, H.M. and M.S. All authors have read and agreed to the published version of the manuscript.

Funding: This research received no external funding.

Acknowledgments: This work was supported by the Hamadan University of Medical Sciences. (grant no. 9611247417).

Conflicts of Interest: The authors declare no conflicts of interest.

\section{References}

1. Wei, J.; Wang, Z.; Wang, Z.; Yang, Y.; Fu, C.; Zhu, J.; Jiang, D. MicroRNA-31 function as a suppressor was regulated by epigenetic mechanisms in gastric cancer. Biomed. Res. Int. 2017, 2017, 11. [CrossRef]

2. Jiang, L.; Meng, W.; Yu, G.; Yin, C.; Wang, Z.; Liao, L.; Meng, F. MicroRNA-144 targets APP to regulate AML1/ETO(+) leukemia cell migration via the p-ERK/c-Myc/MMP-2 pathway. Oncol. Lett. 2019, 18, 2034-2042. [CrossRef]

3. Schelch, K.; Kirschner, M.; Williams, M.; Lin, R.; Cheng, Y.Y.; Grusch, M.; Berger, W.; Van Zandwijk, N.; Reid, G. OA02.01 the microRNA-15/16 family regulates tumor cell growth via fibroblast growth factor signals in malignant pleural mesothelioma. J. Thorac. Oncol. 2017, 12, S246. [CrossRef]

4. Soheilifar, M.H.; Taheri, R.A.; Zolfaghari, E.R.; Moshtaghian, A.; Kooshki, H.; Motie, M.R. Molecular landscape in alveolar soft part sarcoma: Implications for molecular targeted therapy. Biomed. Pharmacother. 2018, 103, 889-896. [CrossRef]

5. Mihalache, A.; Rogoveanu, I. Angiogenesis factors involved in the pathogenesis of colorectal cancer. Curr. Health Sci. J. 2014, 40, 5-11. [CrossRef]

6. Jafarzadeh, N.; Safari, Z.; Pornour, M.; Amirizadeh, N.; Forouzandeh Moghadam, M.; Sadeghizadeh, M. Alteration of cellular and immune-related properties of bone marrow mesenchymal stem cells and macrophages by K562 chronic myeloid leukemia cell derived exosomes. J. Cell Physiol. 2019, 234, 3697-3710. [CrossRef]

7. Zhang, X.; Yuan, X.; Shi, H.; Wu, L.; Qian, H.; Xu, W. Exosomes in cancer: Small particle, big player. J Hematol. Oncol. 2015, 8, 83. [CrossRef]

8. Song, M.-S.; Rossi, J.J. The anti-miR21 antagomir, a therapeutic tool for colorectal cancer, has a potential synergistic effect by perturbing an angiogenesis-associated miR30. Front. Genet. 2014, 4, 301. [CrossRef]

9. Orekhov, A.; Bobryshev, Y. The role of miR-126 in embryonic angiogenesis, adult vascular homeostasis, and vascular repair and its alterations in atherosclerotic disease. J. Mol. Cell Cardiol. 2016, 97. [CrossRef]

10. Cai, M.; Kolluru, G.K.; Ahmed, A. Small Molecule, Big Prospects: MicroRNA in Pregnancy and Its Complications. J. Pregnancy 2017, 2017, 6972732. [CrossRef]

11. Wang, W.; Feng, L.; Zhang, H.; Hachy, S.; Satohisa, S.; Laurent, L.C.; Parast, M.; Zheng, J.; Chen, D.-B. Preeclampsia upregulates angiogenesis-associated microRNA (i.e., miR-17, -20a, and -20b) that target ephrin-B2 and EPHB4 in human placenta. J. Clin. Endocrinol. Metab. 2012, 97, E1051-E1059. [CrossRef]

12. Zhu, Y.; Lu, H.; Huo, Z.; Ma, Z.; Dang, J.; Dang, W.; Pan, L.; Chen, J.; Zhong, H. Microrna-16 Inhibits Feto-Maternal Angiogenesis and Causes Recurrent Spontaneous Abortion by Targeting Vascular Endothelial Growth Factor. Sci. Rep. 2016, 6. [CrossRef]

13. Karami, N.; Mirabutalebi, S.H.; Montazeri, F.; Kalantar, S.M.; Sheikhha, M.H.; Eftekhar, M. Aberrant expression of microRNAs 16 and 21 and gene targets in women with unexplained recurrent miscarriage: A case-control study. Int. J. Repord. Biomed. (Yazd) 2018, 16, 617-622. [CrossRef]

14. Altmäe, S.; Martinez-Conejero, J.A.; Esteban, F.J.; Ruiz-Alonso, M.; Stavreus-Evers, A.; Horcajadas, J.A.; Salumets, A. MicroRNAs miR-30b, miR-30d, and miR-494 regulate human endometrial receptivity. Reprod. Sci. 2013, 20, 308-317. [CrossRef]

15. Braza-Boïls, A.; Gilabert-Estellés, J.; Ramón, L.A.; Gilabert, J.; Marí-Alexandre, J.; Chirivella, M.; España, F.; Estellés, A. Peritoneal Fluid Reduces Angiogenesis-Related MicroRNA Expression in Cell Cultures of Endometrial and Endometriotic Tissues from Women with Endometriosis. PLoS ONE 2013, 8, e62370. [CrossRef] 
16. Wang, T.; Feng, Y.; Sun, H.; Zhang, L.; Hao, L.; Shi, C.; Wang, J.; Li, R.; Ran, X.; Su, Y.; et al. miR-21 Regulates Skin Wound Healing by Targeting Multiple Aspects of the Healing Process. Am. J. Pathol. 2012, 181, 1911-1920. [CrossRef]

17. Hu, Y.; Rao, S.-S.; Wang, Z.-X.; Cao, J.; Tan, Y.-J.; Luo, J.; Li, H.-M.; Zhang, W.-S.; Chen, C.-Y.; Xie, H. Exosomes from human umbilical cord blood accelerate cutaneous wound healing through miR-21-3p-mediated promotion of angiogenesis and fibroblast function. Theranostics 2018, 8, 169-184. [CrossRef]

18. Icli, B.; Nabzdyk, C.S.; Lujan-Hernandez, J.; Cahill, M.; Auster, M.E.; Wara, A.K.; Sun, X.; Ozdemir, D.; Giatsidis, G.; Orgill, D.P.; et al. Regulation of impaired angiogenesis in diabetic dermal wound healing by microRNA-26a. J. Mol. Cell Cardiol. 2016, 91, 151-159. [CrossRef]

19. Wang, J.-M.; Tao, J.; Chen, D.-D.; Cai, J.-J.; Irani, K.; Wang, Q.; Yuan, H.; Chen, A.F. MicroRNA miR-27b rescues bone marrow-derived angiogenic cell function and accelerates wound healing in type 2 diabetes mellitus. Arterioscler. Thromb. Vasc. Biol. 2014, 34, 99-109. [CrossRef]

20. Murata, K.; Ito, H.; Yoshitomi, H.; Yamamoto, K.; Fukuda, A.; Yoshikawa, J.; Furu, M.; Ishikawa, M.; Shibuya, H.; Matsuda, S. Inhibition of miR-92a enhances fracture healing via promoting angiogenesis in a model of stabilized fracture in young mice. J. Bone. Miner. Res. 2014, 29, 316-326. [CrossRef]

21. Liang, X.; Zhang, L.; Wang, S.; Han, Q.; Zhao, R.C. Exosomes secreted by mesenchymal stem cells promote endothelial cell angiogenesis by transferring miR-125a. J. Cell Sci. 2016, 129, 2182-2189. [CrossRef] [PubMed]

22. Wang, S.; Aurora, A.B.; Johnson, B.A.; Qi, X.; McAnally, J.; Hill, J.A.; Richardson, J.A.; Bassel-Duby, R.; Olson, E.N. The endothelial-specific microRNA miR-126 governs vascular integrity and angiogenesis. Dev. Cell 2008, 15, 261-271. [CrossRef] [PubMed]

23. Icli, B.; Wu, W.; Ozdemir, D.; Li, H.; Haemmig, S.; Liu, X.; Giatsidis, G.; Cheng, H.S.; Avci, S.N.; Kurt, M.; et al. MicroRNA-135a-3p regulates angiogenesis and tissue repair by targeting p38 signaling in endothelial cells. FASEB J. 2019, 33, 5599-5614. [CrossRef]

24. Miscianinov, V.; Martello, A.; Rose, L.; Parish, E.; Cathcart, B.; Mitić, T.; Gray, G.A.; Meloni, M.; Zen, A.A.H.; Caporali, A. MicroRNA-148b targets the TGF- $\beta$ pathway to regulate angiogenesis and endothelial-to-mesenchymal transition during skin wound healing. Mol. Ther. 2018, 26, 1996-2007. [CrossRef]

25. Chan, Y.C.; Roy, S.; Huang, Y.; Khanna, S.; Sen, C.K. The microRNA miR-199a-5p downregulation switches on wound angiogenesis by derepressing the v-ets erythroblastosis virus E26 oncogene homolog 1-matrix metalloproteinase-1 pathway. J. Biol. Chem. 2012, 287, 41032-41043. [CrossRef]

26. Icli, B.; Wu, W.; Ozdemir, D.; Li, H.; Cheng, H.S.; Haemmig, S.; Liu, X.; Giatsidis, G.; Avci, S.N.; Lee, N.; et al. MicroRNA-615-5p Regulates Angiogenesis and Tissue Repair by Targeting AKT/eNOS (Protein Kinase B/Endothelial Nitric Oxide Synthase) Signaling in Endothelial Cells. Arterioscler. Thromb. Vasc. Biol. 2019, 39, 1458-1474. [CrossRef]

27. Bhome, R.; Goh, R.W.; Bullock, M.D.; Pillar, N.; Thirdborough, S.M.; Mellone, M.; Mirnezami, R.; Galea, D.; Veselkov, K.; Gu, Q.; et al. Exosomal microRNAs derived from colorectal cancer-associated fibroblasts: Role in driving cancer progression. Aging 2017, 9, 2666-2694. [CrossRef]

28. Mantovani, A.; Marchesi, F.; Malesci, A.; Laghi, L.; Allavena, P. Tumour-associated macrophages as treatment targets in oncology. Nat. Rev. Clin. Oncol. 2017, 14, 399. [CrossRef]

29. Lan, J.; Sun, L.; Xu, F.; Liu, L.; Hu, F.; Song, D.; Hou, Z.; Wu, W.; Luo, X.; Wang, J.; et al. M2 Macrophage-Derived Exosomes Promote Cell Migration and Invasion in Colon Cancer. Cancer Res. 2019, 79, 146-158. [CrossRef]

30. Lin, S.; Jiang, T.; Ye, L.; Han, Z.; Liu, Y.; Liu, C.; Yuan, C.; Zhao, S.; Chen, J.; Wang, J.; et al. The chromatin-remodeling enzyme BRG1 promotes colon cancer progression via positive regulation of WNT3A. Oncotarget 2016, 7, 86051-86063. [CrossRef]

31. Pyo, J.-S.; Son, B.K.; Oh, D.; Kim, E.K. BRG1 is correlated with poor prognosis in colorectal cancer. Hum. Pathol. 2018, 73, 66-73. [CrossRef] [PubMed]

32. Wei, C.; Yang, C.; Wang, S.; Shi, D.; Zhang, C.; Lin, X.; Liu, Q.; Dou, R.; Xiong, B. Crosstalk between cancer cells and tumor associated macrophages is required for mesenchymal circulating tumor cell-mediated colorectal cancer metastasis. Mol. Cancer 2019, 18, 64. [CrossRef] [PubMed]

33. Ye, J.; Wu, X.; Wu, D.; Wu, P.; Ni, C.; Zhang, Z.; Chen, Z.; Qiu, F.; Xu, J.; Huang, J. miRNA-27b targets vascular endothelial growth factor $\mathrm{C}$ to inhibit tumor progression and angiogenesis in colorectal cancer. PLOS ONE 2013, 8, e60687. [CrossRef] [PubMed] 
34. Alasvand, M.; Assadollahi, V.; Ambra, R.; Hedayati, E.; Kooti, W.; Peluso, I. Antiangiogenic effect of Alkaloids. Oxid. Med. Cell Longev. 2019, 2019, 16. [CrossRef]

35. Liu, C.; Eng, C.; Shen, J.; Lu, Y.; Takata, Y.; Mehdizadeh, A.; Chang, G.J.; Rodriguez-Bigas, M.A.; Li, Y.; Chang, P.; et al. Serum exosomal miR-4772-3p is a predictor of tumor recurrence in stage II and III colon cancer. Oncotarget 2016, 7, 76250-76260. [CrossRef] [PubMed]

36. Yamada, N.O.; Heishima, K.; Akao, Y.; Senda, T. Extracellular vesicles containing microRNA-92a-3p facilitate partial endothelial-mesenchymal transition and angiogenesis in endothelial cells. Int. J. Mol. Sci. 2019, 20, 4406. [CrossRef] [PubMed]

37. Yamada, N.; Tsujimura, N.; Kumazaki, M.; Shinohara, H.; Taniguchi, K.; Nakagawa, Y.; Naoe, T.; Akao, Y. Colorectal cancer cell-derived microvesicles containing microRNA-1246 promote angiogenesis by activating Smad 1/5/8 signaling elicited by PML downregulation in endothelial cells. Biochim. Biophys. Acta 2014, 1839. [CrossRef]

38. Hu, H.Y.; Yu, C.H.; Zhang, H.H.; Zhang, S.Z.; Yu, W.Y.; Yang, Y.; Chen, Q. Exosomal miR-1229 derived from colorectal cancer cells promotes angiogenesis by targeting HIPK2. Int. J. Biol. Macromol. 2019, 132, 470-477. [CrossRef]

39. Zeng, Z.; Li, Y.; Pan, Y.; Lan, X.; Song, F.; Sun, J.; Zhou, K.; Liu, X.; Ren, X.; Wang, F.; et al. Cancer-derived exosomal miR-25-3p promotes pre-metastatic niche formation by inducing vascular permeability and angiogenesis. Nat. Commun. 2018, 9, 5395. [CrossRef]

40. Sun, W.; Wang, X.; Li, J.; You, C.; Lu, P.; Feng, H.; Kong, Y.; Zhang, H.; Liu, Y.; Jiao, R.; et al. MicroRNA-181a promotes angiogenesis in colorectal cancer by targeting SRCIN1 to promote the SRC/VEGF signaling pathway. Cell Death Dis. 2018, 9, 438. [CrossRef]

41. Sundaram, P.; Hultine, S.; Smith, L.M.; Dews, M.; Fox, J.L.; Biyashev, D.; Schelter, J.M.; Huang, Q.; Cleary, M.A.; Volpert, O.V.; et al. p53-responsive miR-194 inhibits thrombospondin-1 and promotes angiogenesis in colon cancers. Cancer Res. 2011, 71, 7490-7501. [CrossRef] [PubMed]

42. Colangelo, T.; Fucci, A.; Votino, C.; Sabatino, L.; Pancione, M.; Laudanna, C.; Binaschi, M.; Bigioni, M.; Maggi, C.A.; Parente, D.; et al. MicroRNA-130b promotes tumor development and is associated with poor prognosis in colorectal cancer. Neoplasia 2013, 15, 1086-1099. [CrossRef] [PubMed]

43. Xu, Q.; Tong, J.-L.; Zhang, C.-P.; Xiao, Q.; Lin, X.-L.; Xiao, X.-Y. miR-27a induced by colon cancer cells in HLECs promotes lymphangiogenesis by targeting SMAD4. PLoS ONE 2017, 12, e0186718. [CrossRef] [PubMed]

44. Xu, Z.; Zhu, C.; Chen, C.; Zong, Y.; Feng, H.; Liu, D.; Feng, W.; Zhao, J.; Lu, A. CCL19 suppresses angiogenesis through promoting miR-206 and inhibiting Met/ERK/Elk-1/HIF-1 $\alpha /$ VEGF-A pathway in colorectal cancer. Cell Death Dis. 2018, 9, 974. [CrossRef]

45. Zhang, Y.; Wang, X.; Xu, B.; Wang, B.; Wang, Z.; Liang, Y.; Zhou, J.; Hu, J.; Jiang, B. Epigenetic silencing of miR-126 contributes to tumor invasion and angiogenesis in colorectal cancer. Oncol. Rep. 2013, 30, 1976-1984. [CrossRef]

46. Qian, X.; Yu, J.; Yin, Y.; He, J.; Wang, L.; Li, Q.; Zhang, L.-Q.; Li, C.-Y.; Shi, Z.-M.; Xu, Q.; et al. MicroRNA-143 inhibits tumor growth and angiogenesis and sensitizes chemosensitivity to oxaliplatin in colorectal cancers. Cell Cycle 2013, 12, 1385-1394. [CrossRef]

47. Chen, X.; Zeng, K.; Xu, M.; Liu, X.; Hu, X.; Xu, T.; He, B.; Pan, Y.; Sun, H.; Wang, S. P53-induced miR-1249 inhibits tumor growth, metastasis, and angiogenesis by targeting VEGFA and HMGA2. Cell Death Dis. 2019, 10, 131. [CrossRef]

48. Zhou, Q.; Zhu, Y.; Wei, X.; Zhou, J.; Chang, L.; Sui, H.; Han, Y.; Piao, D.; Sha, R.; Bai, Y. MiR-590-5p inhibits colorectal cancer angiogenesis and metastasis by regulating nuclear factor 90/vascular endothelial growth factor A axis. Cell Death Dis. 2016, 7, e2413. [CrossRef]

49. Lun, W.; Wu, X.; Deng, Q.; Zhi, F. MiR-218 regulates epithelial-mesenchymal transition and angiogenesis in colorectal cancer via targeting CTGF. Cancer Cell Int. 2018, 18, 83. [CrossRef]

50. Wang, Y.; Wu, M.; Lei, Z.; Huang, M.; Li, Z.; Wang, L.; Cao, Q.; Han, D.; Chang, Y.; Chen, Y.; et al. Dysregulation of miR-6868-5p/FOXM1 circuit contributes to colorectal cancer angiogenesis. J Exp Clin Cancer Res. 2018, 37. [CrossRef]

51. Yamakuchi, M.; Lotterman, C.D.; Bao, C.; Hruban, R.H.; Karim, B.; Mendell, J.T.; Huso, D.; Lowenstein, C.J. P53-induced microRNA-107 inhibits HIF-1 and tumor angiogenesis. Proc. Natl. Acad. Sci. USA 2010, 107, 6334-6339. [CrossRef] [PubMed] 
52. Chen, X.; Zeng, K.; Xu, M.; Hu, X.; Liu, X.; Xu, T.; He, B.; Pan, Y.; Sun, H.; Wang, S. SP1-induced lncRNA-ZFAS1 contributes to colorectal cancer progression via the miR-150-5p/VEGFA axis. Cell Death Dis. 2018, 9, 982. [CrossRef] [PubMed]

53. Liang, L.; Gao, C.; Li, Y.; Sun, M.; Xu, J.; Li, H.; Jia, L.; Zhao, Y. miR-125a-3p/FUT5-FUT6 axis mediates colorectal cancer cell proliferation, migration, invasion and pathological angiogenesis via PI3K-Akt pathway. Cell Death Dis 2017, 8, e2968. [CrossRef] [PubMed]

54. Yang, X.; Qiu, J.; Kang, H.; Wang, Y.; Qian, J. miR-125a-5p suppresses colorectal cancer progression by targeting VEGFA. Cancer Manag. Res. 2018, 10, 5839-5853. [CrossRef] [PubMed]

55. Zhang, W.; Zou, C.; Pan, L.; Xu, Y.; Qi, W.; Ma, G.; Hou, Y.; Jiang, P. MicroRNA-140-5p inhibits the progression of colorectal cancer by targeting VEGFA. Cell Physiol. Biochem. 2015, 37, 1123-1133. [CrossRef] [PubMed]

56. Xu, Q.; Liu, L.-Z.; Qian, X.; Chen, Q.; Jiang, Y.; Li, D.; Lai, L.; Jiang, B.-H. MiR-145 directly targets p70S6K1 in cancer cells to inhibit tumor growth and angiogenesis. Nucleic Acids Res. 2011, 40, 761-774. [CrossRef]

57. Forouzan Jahromi, Z.; Javeri, A.; Fakhr Taha, M. Tumor suppressive effects of the pleiotropically acting miR-195 in colorectal cancer cells. EXCLI J. 2019, 18, 243-252. [CrossRef]

58. Fang, Y.; Sun, B.; Wang, J.; Wang, Y. miR-622 inhibits angiogenesis by suppressing the CXCR4-VEGFA axis in colorectal cancer. Gene 2019, 699, 37-42. [CrossRef]

59. Mo, J.S.; Park, W.C.; Choi, S.-C.; Yun, K.J.; Chae, S.-C. MicroRNA 452 Regulates cell proliferation, cell migration, and angiogenesis in colorectal cancer by suppressing VEGFA expression. Cancers 2019, 11, 1613. [CrossRef]

60. Iaconetti, C.; Polimeni, A.; Sorrentino, S.; Sabatino, J.; Pironti, G.; Esposito, G.; Curcio, A.; Indolfi, C. Inhibition of miR-92a increases endothelial proliferation and migration in vitro as well as reduces neointimal proliferation in vivo after vascular injury. Basic Res. Cardiol. 2012, 107, 296. [CrossRef]

61. Bonauer, A.; Carmona, G.; Iwasaki, M.; Mione, M.; Koyanagi, M.; Fischer, A.; Burchfield, J.; Fox, H.; Doebele, C.; Ohtani, K. MicroRNA-92a controls angiogenesis and functional recovery of ischemic tissues in mice. Science 2009, 324, 1710-1713. [CrossRef] [PubMed]

62. Bai, Y.; Wang, W.; Zhang, Y.; Zhang, F.; Zhang, H. lncRNA MIAT suppression alleviates corneal angiogenesis through regulating miR-1246/ACE. Cell Cycle 2019, 18, 661-669. [CrossRef] [PubMed]

63. Sun, X.; Charbonneau, C.; Wei, L.; Chen, Q.; Terek, R.M. MiR-181a targets RGS16 to promote chondrosarcoma growth, angiogenesis, and metastasis. Mol. Cancer Res. 2015, 13, 1347-1357. [CrossRef] [PubMed]

64. Urbich, C.; Kaluza, D.; Frömel, T.; Knau, A.; Bennewitz, K.; Boon, R.; Bonauer, A.; Doebele, C.; Boeckel, J.-N.; Hergenreider, E.; et al. MicroRNA-27a/b controls endothelial cell repulsion and angiogenesis by targeting semaphorin 6A. Blood 2011, 119, 1607-1616. [CrossRef]

65. Isanejad, A.; Alizadeh, A.M.; Amani-Shalamzari, S.; Khodayari, H.; Khodayari, S.; Khori, V.; Khojastehnjad, N. MicroRNA-206, Let-7 and microRNA-21 pathways involved in the anti-angiogenesis effects of the interval exercise training and hormone therapy in breast cancer. Life Sci. 2016, 151. [CrossRef]

66. Chen, Q.-Y.; Jiao, D.-M.; Wu, Y.; Chen, J.; Wang, J.; Tang, X.-L.; Mou, H.; Hu, H.-Z.; Song, J.; Yan, J.; et al. MiR-206 inhibits HGF-induced epithelial-mesenchymal transition and angiogenesis in non-small cell lung cancer via c-Met /PI3k/ Akt/mTOR pathway. Oncotarget 2016, 7. [CrossRef]

67. Zhang, T.; Liu, M.; Wang, C.; Lin, C.; Sun, Y.; Jin, D. Downregulation of MiR-206 promotes proliferation and invasion of laryngeal cancer by regulating VEGF expression. Anticancer Res 2011, 31, 3859-3863.

68. Liang, Z.; Bian, X.; Shim, H. Downregulation of microRNA-206 promotes invasion and angiogenesis of triple negative breast cancer. Biochem. Biophys. Res. Commun. 2016, 477, 461-466. [CrossRef]

69. Chen, H.; Li, L.; Wang, S.; Lei, Y.; Ge, Q.; Lv, N.; Zhou, X.; Chen, C. Reduced miR-126 expression facilitates angiogenesis of gastric cancer through its regulation on VEGF-A. Oncotarget 2014, 5, 11873. [CrossRef]

70. Sasahira, T.; Kurihara, M.; Bhawal, U.; Ueda, N.; Shimomoto, T.; Yamamoto, K.; Kirita, T.; Kuniyasu, H. Downregulation of miR-126 induces angiogenesis and lymphangiogenesis by activation of VEGF-A in oral cancer. Br. J. Cancer 2012, 107, 700-706. [CrossRef]

71. Alhasan, L. MiR-126 Modulates Angiogenesis in Breast Cancer by Targeting VEGF-A-mRNA. Asian Pac. J. Cancer Prev. 2019, 20, 193-197. [CrossRef] [PubMed]

72. Zhu, N.; Zhang, D.; Xie, H.; Zhou, Z.; Chen, H.; Hu, T.; Bai, Y.; Shen, Y.; Yuan, W.; Jing, Q. Endothelial-specific intron-derived miR-126 is downregulated in human breast cancer and targets both VEGFA and PIK3R2. Mol. Cell Biochem. 2011, 351, 157-164. [CrossRef] [PubMed] 
73. Hu, J.; Zeng, L.; Huang, J.; Wang, G.; Lu, H. miR-126 promotes angiogenesis and attenuates inflammation after contusion spinal cord injury in rats. Brain Res. 2015, 1608, 191-202. [CrossRef] [PubMed]

74. Qu, M.; Pan, J.; Wang, L.; Zhou, P.; Song, Y.; Wang, S.; Jiang, L.; Geng, J.; Zhang, Z.; Wang, Y. MicroRNA-126 regulates angiogenesis and neurogenesis in a mouse model of focal cerebral ischemia. Mol. Ther. Nucleic. Acids 2019, 16, 15-25. [CrossRef]

75. Li, Y.; Tian, L.; Sun, D.; Yin, D. Curcumin ameliorates atherosclerosis through upregulation of miR-126. J. Cell Physiol. 2019, 234, 21049-21059. [CrossRef]

76. Lu, Y.; Qin, T.; Li, J.; Wang, L.; Zhang, Q.; Jiang, Z.; Mao, J. MicroRNA-140-5p inhibits invasion and angiogenesis through targeting VEGF-A in breast cancer. Cancer Gene Ther. 2017, 24, 386-392. [CrossRef]

77. Zhang, J.; Zhu, R.; Han, X. MiR-140-5p inhibits larynx carcinoma invasion and angiogenesis by targeting VEGF-A. Eur. Rev. Med. Pharmacol. Sci. 2018, 22, 5994-6001.

78. Liu, C.-H.; Wang, Z.; Huang, S.; Sun, Y.; Chen, J. MicroRNA-145 regulates pathological retinal angiogenesis by suppression of TMOD3. Mol. Ther. Nucleic. Acids 2019, 16, 335-347. [CrossRef]

79. Hu, Y.; Li, Y.; Wu, C.; Zhou, L.; Han, X.; Wang, Q.; Xie, X.; Zhou, Y.; Du, Z. MicroRNA-140-5p inhibits cell proliferation and invasion by regulating VEGFA/MMP2 signaling in glioma. Tumour Biol. 2017, 39, 1010428317697558. [CrossRef]

80. Dimitrova, N.; Gocheva, V.; Bhutkar, A.; Resnick, R.; Jong, R.M.; Miller, K.M.; Bendor, J.; Jacks, T. Stromal Expression of miR-143/145 Promotes neoangiogenesis in lung cancer development. Cancer Discov. 2016, 6, 188-201. [CrossRef]

81. Zou, C.; Xu, Q.; Mao, F.; Li, D.; Bian, C.; Liu, L.-Z.; Jiang, Y.; Chen, X.; Qi, Y.; Zhang, X. MiR-145 inhibits tumor angiogenesis and growth by N-RAS and VEGF. Cell Cycle 2012, 11, 2137-2145. [CrossRef]

82. Zhang, H.; Pu, J.; Qi, T.; Qi, M.; Yang, C.; Li, S.; Huang, K.; Zheng, L.; Tong, Q. MicroRNA-145 inhibits the growth, invasion, metastasis and angiogenesis of neuroblastoma cells through targeting hypoxia-inducible factor 2 alpha. Oncogene 2014, 33, 387-397. [CrossRef] [PubMed]

83. Irani, S.; Shokri, G. The role of miR-143, miR-145, and miR-590 in expression levels of CD44 and vascular endothelial cadherin in oral squamous cell carcinoma. Middle East J. Cancer. 2019, 10, 288-294. [CrossRef]

84. Chen, L.; Li, Z.-Y.; Xu, S.-Y.; Zhang, X.-J.; Zhang, Y.; Luo, K.; Li, W.-P. Upregulation of miR-107 inhibits glioma angiogenesis and VEGF expression. Cell Mol. Neurobiol. 2016, 36, 113-120. [CrossRef] [PubMed]

85. Lu, Z.; Xiao, Z.; Liu, F.; Cui, M.; Li, W.; Yang, Z.; Li, J.; Ye, L.; Zhang, X. Long non-coding RNA HULC promotes tumor angiogenesis in liver cancer by upregulating sphingosine kinase 1 (SPHK1). Oncotarget 2016, 7, 241-254. [PubMed]

86. Li, Y.; Mao, L.; Gao, Y.; Baral, S.; Zhou, Y.; Hu, B. MicroRNA-107 contributes to post-stroke angiogenesis by targeting Dicer-1. Sci. Rep. 2015, 5, 13316. [CrossRef] [PubMed]

87. Hunter, S.; Nault, B.; Ugwuagbo, K.C.; Maiti, S.; Majumder, M. Mir526b and Mir655 Promote Tumour Associated Angiogenesis and Lymphangiogenesis in Breast Cancer. Cancers 2019, 11, 938. [CrossRef]

88. Kim, T.H.; Jeong, J.-Y.; Park, J.-Y.; Kim, S.-W.; Heo, J.H.; Kang, H.; Kim, G.; An, H.J. miR-150 enhances apoptotic and anti-tumor effects of paclitaxel in paclitaxel-resistant ovarian cancer cells by targeting Notch3. Oncotarget 2017, 8, 72788-72800. [CrossRef]

89. Chen, Z.; Wang, H.; Xia, Y.; Yan, F.; Lu, Y. Therapeutic Potential of Mesenchymal Cell-Derived miRNA-150-5p-Expressing Exosomes in Rheumatoid Arthritis Mediated by the Modulation of MMP14 and VEGF. J. Immunol. 2018, 201, 2472-2482. [CrossRef]

90. Hou, P.; Li, H.; Yong, H.; Chen, F.; Chu, S.; Zheng, J.; Bai, J. PinX1 represses renal cancer angiogenesis via the mir-125a-3p/VEGF signaling pathway. Angiogenesis 2019, 22, 507-519. [CrossRef]

91. Dai, J.; Wang, J.; Yang, L.; Xiao, Y.; Ruan, Q. miR-125a regulates angiogenesis of gastric cancer by targeting vascular endothelial growth factor A. Int. J. Oncol. 2015, 47, 1801-1810. [CrossRef] [PubMed]

92. Lee, M.; Kim, E.J.; Jeon, M.J. MicroRNAs 125a and 125b inhibit ovarian cancer cells through post-transcriptional inactivation of EIF4EBP1. Oncotarget 2016, 7, 8726-8742. [CrossRef] [PubMed]

93. Alpini, G.; Glaser, S.S.; Zhang, J.P.; Francis, H.; Han, Y.; Gong, J.; Stokes, A.; Francis, T.; Hughart, N.; Hubble, L.; et al. Regulation of placenta growth factor by microRNA-125b in hepatocellular cancer. J. Hepatol. 2011, 55, 1339-1345. [CrossRef] [PubMed]

94. Liu, H.; Chen, Y.; Li, Y.; Li, C.; Qin, T.; Bai, M.; Zhang, Z.; Jia, R.; Su, Y.; Wang, C. miR-195 suppresses metastasis and angiogenesis of squamous cell lung cancer by inhibiting the expression of VEGF. Mol. Med. Rep. 2019, 20, 2625-2632. [CrossRef] 
95. Dai, J.; Wei, R.; Zhang, P.; Kong, B. Overexpression of microRNA-195-5p reduces cisplatin resistance and angiogenesis in ovarian cancer by inhibiting the PSAT1-dependent GSK3 $\beta / \beta$-catenin signaling pathway. J. Transl. Med. 2019, 17, 190. [CrossRef] [PubMed]

96. Wang, R.; Zhao, N.; Li, S.; Fang, J.H.; Chen, M.X.; Yang, J.; Jia, W.H.; Yuan, Y.; Zhuang, S.M. MicroRNA-195 suppresses angiogenesis and metastasis of hepatocellular carcinoma by inhibiting the expression of VEGF, VAV2, and CDC42. Hepatology 2013, 58, 642-653. [CrossRef] [PubMed]

97. Cai, C.; He, H.; Duan, X.; Wu, W.; Mai, Z.; Zhang, T.; Fan, J.; Deng, T.; Zhong, W.; Liu, Y. miR-195 inhibits cell proliferation and angiogenesis in human prostate cancer by downregulating PRR11 expression. Oncol. Rep. 2018, 39, 1658-1670. [CrossRef]

98. Zhang, X.; Dong, J.; He, Y.; Zhao, M.; Liu, Z.; Wang, N.; Jiang, M.; Zhang, Z.; Liu, G.; Liu, H. miR-218 inhibited tumor angiogenesis by targeting ROBO1 in gastric cancer. Gene 2017, 615, 42-49. [CrossRef]

99. Guan, B.; Wu, K.; Zeng, J.; Xu, S.; Mu, L.; Gao, Y.; Wang, K.; Ma, Z.; Tian, J.; Shi, Q. Tumor-suppressive microRNA-218 inhibits tumor angiogenesis via targeting the mTOR component RICTOR in prostate cancer. Oncotarget 2017, 8, 8162-8172. [CrossRef]

100. Kim, M.; Jang, K.; Miller, P.; Picon-Ruiz, M.; Yeasky, T.M.; El-Ashry, D.; Slingerland, J.M. VEGFA links self-renewal and metastasis by inducing Sox2 to repress miR-452, driving Slug. Oncogene 2017, 36, 5199-5211. [CrossRef]

101. Ma, H.; Pan, J.-S.; Jin, L.-X.; Wu, J.; Ren, Y.-D.; Chen, P.; Xiao, C.; Han, J. MicroRNA-17 92 inhibits colorectal cancer progression by targeting angiogenesis. Cancer Lett. 2016, 376, 293-302. [CrossRef]

102. Lv, H.; Zhang, Z.; Wang, Y.; Li, C.; Gong, W.; Wang, X. MicroRNA-92a Promotes Colorectal Cancer Cell Growth and Migration by Inhibiting KLF4. Oncol. Rep. 2016, 23, 283-290. [CrossRef] [PubMed]

103. Lorsy, E.; Topuz, A.S.; Geisler, C.; Stahl, S.; Garczyk, S.; von Stillfried, S.; Hoss, M.; Gluz, O.; Hartmann, A.; Knüchel, R.; et al. Loss of Dickkopf 3 Promotes the Tumorigenesis of Basal Breast Cancer. PLoS ONE 2016, 11, e0160077. [CrossRef] [PubMed]

104. Al Shareef, Z.; Kardooni, H.; Murillo-Garzón, V.; Domenici, G.; Stylianakis, E.; Steel, J.H.; Rabano, M.; Gorroño-Etxebarria, I.; Zabalza, I.; Vivanco, M.D.; et al. Protective effect of stromal Dickkopf-3 in prostate cancer: Opposing roles for TGFBI and ECM-1. Oncogene 2018, 37, 5305-5324. [CrossRef] [PubMed]

105. Guo, Q.; Qin, W. DKK3 blocked translocation of $\beta$-catenin/EMT induced by hypoxia and improved gemcitabine therapeutic effect in pancreatic cancer Bxpc-3 cell. J Cell Mol. Med. 2015, 19, 2832-2841. [CrossRef] [PubMed]

106. Zhou, L.; Husted, H.; Moore, T.; Lu, M.; Deng, D.; Liu, Y.; Ramachandran, V.; Arumugam, T.; Niehrs, C.; Wang, H.; et al. Suppression of stromal-derived Dickkopf-3 (DKK3) inhibits tumor progression and prolongs survival in pancreatic ductal adenocarcinoma. Sci. Transl. Med. 2018, 10, eaat3487. [CrossRef]

107. Busceti, C.L.; Marchitti, S.; Bianchi, F.; Di Pietro, P.; Riozzi, B.; Stanzione, R.; Cannella, M.; Battaglia, G.; Bruno, V.; Volpe, M.; et al. Dickkopf-3 upregulates VEGF in cultured human endothelial cells by activating activin receptor-like kinase 1 (ALK1) pathway. Front. Pharmacol. 2017, 8, 111. [CrossRef]

108. Zitt, M.; Untergasser, G.; Amberger, A.; Moser, P.; Stadlmann, S.; Zitt, M.; Müller, H.; Mühlmann, G.; Perathoner, A.; Margreiter, R.; et al. Dickkopf-3 As a new potential marker for neoangiogenesis in colorectal cancer: Expression in cancer tissue and adjacent non-cancerous tissue. Dis. Markers 2008, 24, 101-109. [CrossRef]

109. Kim, B.R.; Lee, E.J.; Seo, S.H.; Lee, S.H.; Rho, S.B. Dickkopf-3 (DKK-3) obstructs VEGFR-2/Akt/mTOR signaling cascade by interacting of beta2-microglobulin (beta2M) in ovarian tumorigenesis. Cell Signal. 2015, 27, 2150-2159. [CrossRef]

110. Safari, E.; Mosayebi, G.; Khorram, S. Dkk-3 as a potential biomarker for diagnosis and prognosis of colorectal cancer. Med. J. Islam. Repub. Iran 2018, 32, 502-506. [CrossRef]

111. Wallez, Y.; Huber, P. Endothelial adherens and tight junctions in vascular homeostasis, inflammation and angiogenesis. Biochim. Biophys. Acta 2008, 1778, 794-809. [CrossRef] [PubMed]

112. Li, J.; Zhou, C.; Ni, S.; Wang, S.; Ni, C.; Yang, P.; Ye, M. Methylated claudin-11 associated with metastasis and poor survival of colorectal cancer. Oncotarget 2017, 8, 96249-96262. [CrossRef] [PubMed]

113. Wei, C.; Li, Y.; Huang, K.; Li, G.; He, M. Exosomal miR-1246 in body fluids is a potential biomarker for gastrointestinal cancer. Biomarkers Med. 2018, 12, 1185-1196. [CrossRef] [PubMed]

114. Chen, B.; Xia, Z.; Deng, Y.N.; Yang, Y.; Zhang, P.; Zhu, H.; Xu, N.; Liang, S. Emerging microRNA biomarkers for colorectal cancer diagnosis and prognosis. Open Biol. 2019, 9, 180212. [CrossRef] 
115. Wang, S.; Zeng, Y.; Zhou, J.M.; Nie, S.L.; Peng, Q.; Gong, J.; Huo, J.R. MicroRNA-1246 promotes growth and metastasis of colorectal cancer cells involving CCNG2 reduction. Mol. Med. Rep. 2016, 13, 273-280. [CrossRef]

116. Toden, S.; Kunitoshi, S.; Cardenas, J.; Gu, J.; Hutchins, E.; Van Keuren-Jensen, K.; Uetake, H.; Toiyama, Y.; Goel, A. Cancer stem cell-associated miRNAs serve as prognostic biomarkers in colorectal cancer. JCI Insight 2019, 4. [CrossRef]

117. Peng, W.; Li, J.; Chen, R.; Gu, Q.; Yang, P.; Qian, W.; Ji, D.; Wang, Q.; Zhang, Z.; Tang, J.; et al. Upregulated METTL3 promotes metastasis of colorectal Cancer via miR-1246/SPRED2/MAPK signaling pathway. J. Exp. Clin. Cancer Res. 2019, 38, 393. [CrossRef]

118. Guerrero, P.A.; McCarty, J.H. TGF- $\beta$ activation and signaling in angiogenesis. Physiol. Pathol. Angiogenesis-Signal. Mech. Target. Ther. 2017. [CrossRef]

119. Lin, S.; Xie, J.; Gong, T.; Shi, S.; Zhang, T.; Fu, N.; Lin, Y. Smad signal pathway regulates angiogenesis via endothelial cell in an adipose-derived stromal cell/endothelial cell co-culture, 3D gel model. Mol Cell Biochem. 2016, 412, 281-288. [CrossRef]

120. Budi, E.H.; Mamai, O.; Hoffman, S.; Akhurst, R.J.; Derynck, R. Enhanced TGF-beta Signaling Contributes to the Insulin-Induced Angiogenic Responses of Endothelial Cells. iScience 2019, 11, 474-491. [CrossRef]

121. Hsu, K.-S.; Kao, H.-Y. PML: Regulation and multifaceted function beyond tumor suppression. Cell Biosci. 2018, 8, 5. [CrossRef] [PubMed]

122. Kacan, T.; Nayir, E.; Altun, A.; Kilickap, S.; Babacan, N.A.; Ataseven, H.; Kaya, T. Antitumor activity of sorafenib on colorectal cancer. JOS 2016, 2, 53-57. [CrossRef]

123. Pehserl, A.-M.; Ress, A.L.; Stanzer, S.; Resel, M.; Karbiener, M.; Stadelmeyer, E.; Stiegelbauer, V.; Gerger, A.; Mayr, C.; Scheideler, M.; et al. Comprehensive analysis of miRNome alterations in response to sorafenib treatment in colorectal cancer cells. Int. J. Mol. Sci. 2016, 17, 2011. [CrossRef] [PubMed]

124. Guo, S.; Zhang, J.; Wang, B.; Zhang, B.; Wang, X.; Huang, L.; Liu, H.; Jia, B. A 5-serum miRNA panel for the early detection of colorectal cancer. Oncol. Targets Ther. 2018, 11, 2603-2614. [CrossRef] [PubMed]

125. Joseph, R.W.; Parasramka, M.; Eckel-Passow, J.E.; Serie, D.; Wu, K.; Jiang, L.; Kalari, K.; Thompson, R.H.; Huu Ho, T.; Castle, E.P.; et al. Inverse association between programmed death ligand 1 and genes in the VEGF pathway in primary clear cell renal cell carcinoma. Cancer Immunol. Res. 2013, 1, 378-385. [CrossRef]

126. Puca, R.; Nardinocchi, L.; Givol, D.; D'Orazi, G. Regulation of p53 activity by HIPK2: Molecular mechanisms and therapeutical implications in human cancer cells. Oncogene 2010, 29, 4378-4387. [CrossRef]

127. Li, X.; Yang, C.; Wang, X.; Zhang, J.; Zhang, R.; Liu, R. The expression of miR-25 is increased in colorectal cancer and is associated with patient prognosis. Med. Oncol. 2014, 31, 781. [CrossRef]

128. Li, Q.; Zou, C.; Zou, C.; Han, Z.; Xiao, H.; Wei, H.; Wang, W.; Zhang, L.; Zhang, X.; Tang, Q.; et al. MicroRNA-25 functions as a potential tumor suppressor in colon cancer by targeting Smad7. Cancer Lett. 2013, 335, 168-174. [CrossRef]

129. Wang, H.G.; Cao, B.; Zhang, L.X.; Song, N.; Li, H.; Zhao, W.Z.; Li, Y.S.; Ma, S.M.; Yin, D.J. KLF2 inhibits cell growth via regulating HIF-1alpha/Notch-1 signal pathway in human colorectal cancer HCT116 cells. Oncol. Rep. 2017, 38, 584-590. [CrossRef]

130. Ma, Y.; Wu, L.; Liu, X.; Xu, Y.; Shi, W.; Liang, Y.; Yao, L.; Zheng, J.; Zhang, J. KLF4 inhibits colorectal cancer cell proliferation dependent on NDRG2 signaling. Oncol. Rep. 2017, 38, 975-984. [CrossRef]

131. Li, Y.; Kuscu, C.; Banach, A.; Zhang, Q.; Pulkoski-Gross, A.; Kim, D.; Liu, J.; Roth, E.; Li, E.; Shroyer, K.R.; et al. miR-181a-5p Inhibits Cancer Cell Migration and Angiogenesis via Downregulation of Matrix Metalloproteinase-14. Cancer Res. 2015, 75, 2674-2685. [CrossRef] [PubMed]

132. Abu El-Asrar, A.M.; Mohammad, G.; Allegaert, E.; Ahmad, A.; Siddiquei, M.M.; Alam, K.; Gikandi, P.W.; De Hertogh, G.; Opdenakker, G. Matrix metalloproteinase-14 is a biomarker of angiogenic activity in proliferative diabetic retinopathy. Mol. Vis. 2018, 24, 394-406. [PubMed]

133. Han, K.Y.; Chang, J.H.; Lee, H.; Azar, D.T. Proangiogenic Interactions of Vascular Endothelial MMP14 With VEGF Receptor 1 in VEGFA-Mediated Corneal Angiogenesis. Investig. Ophthalmol. Vis. Sci. 2016, 57, 3313-3322. [CrossRef] [PubMed]

134. Hui, P.; Xu, X.; Xu, L.; Hui, G.; Wu, S.; Lan, Q. Expression of MMP14 in invasive pituitary adenomas: Relationship to invasion and angiogenesis. Int. J. Clin. Exp. Pathol. 2015, 8, 3556-3567. [PubMed]

135. Cai, H.-K.; Chen, X.; Tang, Y.-H.; Deng, Y.-C. MicroRNA-194 modulates epithelial-mesenchymal transition in human colorectal cancer metastasis. Onco. Targets Ther. 2017, 10, 1269-1278. [CrossRef] [PubMed] 
136. Wang, B.; Shen, Z.L.; Gao, Z.D.; Zhao, G.; Wang, C.Y.; Yang, Y.; Zhang, J.Z.; Yan, Y.C.; Shen, C.; Jiang, K.W.; et al. MiR-194, commonly repressed in colorectal cancer, suppresses tumor growth by regulating the MAP4K4/c-Jun/MDM2 signaling pathway. Cell Cycle 2015, 14, 1046-1058. [CrossRef]

137. Przygodzka, P.; Papiewska-Pajak, I.; Bogusz-Koziarska, H.; Sochacka, E.; Boncela, J.; Kowalska, M.A. Regulation of miRNAs by Snail during epithelial-to-mesenchymal transition in HT29 colon cancer cells. Sci. Rep. 2019, 9, 2165. [CrossRef]

138. Liang, J.; Tang, J.; Shi, H.; Li, H.; Zhen, T.; Duan, J.; Kang, L.; Zhang, F.; Dong, Y.; Han, A. miR-27a-3p targeting RXRalpha promotes colorectal cancer progression by activating Wnt/beta-catenin pathway. Oncotarget 2017, 8, 82991-83008. [CrossRef]

139. Ruan, H.; Zhan, Y.Y.; Hou, J.; Xu, B.; Chen, B.; Tian, Y.; Wu, D.; Zhao, Y.; Zhang, Y.; Chen, X.; et al. Berberine binds RXR $\alpha$ to suppress $\beta$-catenin signaling in colon cancer cells. Oncogene 2017, 36, 6906. [CrossRef]

140. Colangelo, T.; Polcaro, G.; Ziccardi, P.; Muccillo, L.; Galgani, M.; Pucci, B.; Milone, M.R.; Budillon, A.; Santopaolo, M.; Mazzoccoli, G.; et al. The miR-27a-calreticulin axis affects drug-induced immunogenic cell death in human colorectal cancer cells. Cell Death Dis. 2016, 7, e2108. [CrossRef]

141. Colangelo, T.; Polcaro, G.; Ziccardi, P.; Pucci, B.; Muccillo, L.; Galgani, M.; Fucci, A.; Milone, M.R.; Budillon, A.; Santopaolo, M.; et al. Proteomic screening identifies calreticulin as a miR-27a direct target repressing MHC class I cell surface exposure in colorectal cancer. Cell Death Dis. 2016, 7, e2120. [CrossRef] [PubMed]

142. Zhao, Y.; Miao, G.; Li, Y.; Isaji, T.; Gu, J.; Li, J.; Qi, R. Microrna 130b Suppresses Migration and Invasion of Colorectal Cancer Cells through Downregulation of Integrin $\beta 1$. PLoS ONE 2014, 9, e87938. [CrossRef] [PubMed]

143. Luo, Y.; Yu, S.Y.; Chen, J.J.; Qin, J.; Qiu, Y.E.; Zhong, M.; Chen, M. MiR-27b directly targets Rab3D to inhibit the malignant phenotype in colorectal cancer. Oncotarget 2018, 9, 3830-3841. [CrossRef] [PubMed]

144. Sweat, R.S.; Sloas, D.C.; Murfee, W.L. VEGF-C induces lymphangiogenesis and angiogenesis in the rat mesentery culture model. Microcirculation 2014, 21, 532-540. [CrossRef]

145. Singh, N.K.; Kotla, S.; Kumar, R.; Rao, G.N. Cyclic AMP Response Element Binding Protein Mediates Pathological Retinal Neovascularization via Modulating DLL4-NOTCH1 Signaling. EBioMedicine 2015, 2, 1767-1784. [CrossRef]

146. Khromova, N.; Kopnin, P.; Rybko, V.; Kopnin, B.P. Downregulation of VEGF-C expression in lung and colon cancer cells decelerates tumor growth and inhibits metastasis via multiple mechanisms. Oncogene 2012, 31, 1389-1397. [CrossRef]

147. Tacconi, C.; Ungaro, F.; Correale, C.; Arena, V.; Massimino, L.; Detmar, M.; Spinelli, A.; Carvello, M.; Mazzone, M.; Oliveira, A.I.; et al. Activation of the VEGFC/VEGFR3 pathway induces tumor immune escape in colorectal cancer. Cancer Res. 2019, 79, 4196-4210. [CrossRef]

148. Sun, P.; Sun, D.; Wang, X.; Liu, T.; Ma, Z.; Duan, L. miR-206 is an independent prognostic factor and inhibits tumor invasion and migration in colorectal cancer. Cancer Biomark 2015, 15, 391-396. [CrossRef]

149. Park, Y.R.; Seo, S.Y.; Kim, S.L.; Zhu, S.M.; Chun, S.; Oh, J.-M.; Lee, M.R.; Kim, S.H.; Kim, I.H.; Lee, S.O.; et al. MiRNA-206 suppresses PGE2-induced colorectal cancer cell proliferation, migration, and invasion by targetting TM4SF1. Biosci. Rep. 2018, 38, BSR20180664. [CrossRef]

150. Wang, X.W.; Xi, X.Q.; Wu, J.; Wan, Y.Y.; Hui, H.X.; Cao, X.F. MicroRNA-206 attenuates tumor proliferation and migration involving the downregulation of NOTCH3 in colorectal cancer. Oncol. Rep. 2015, 33, 1402-1410. [CrossRef]

151. Meng, X.; Fu, R. miR-206 regulates 5-FU resistance by targeting Bcl-2 in colon cancer cells. Oncol. Targets Ther. 2018, 11, 1757-1765. [CrossRef] [PubMed]

152. Ebrahimi, F.; Gopalan, V.; Wahab, R.; Lu, C.-T.; Anthony Smith, R.; Lam, A.K.-Y. Deregulation of miR-126 expression in colorectal cancer pathogenesis and its clinical significance. Exp. Cell Res. 2015, 339, 333-341. [CrossRef] [PubMed]

153. Li, N.; Li, X.; Huang, S.; Shen, S.; Wang, X. [miR-126 inhibits colon cancer proliferation and invasion through targeting IRS1, SLC7A5 and TOM1 gene]. Zhong Nan Da Xue Xue Bao Yi Xue Ban = J. Cent. South Univ. Med. Sci. 2013, 38, 809-817. [CrossRef]

154. Li, Z.; Li, N.; Wu, M.; Li, X.; Luo, Z.; Wang, X. Expression of miR-126 suppresses migration and invasion of colon cancer cells by targeting CXCR4. Mol. Cell Biochem. 2013, 381, 233-242. [CrossRef] [PubMed] 
155. Liu, Y.; Zhou, Y.; Feng, X.; An, P.; Quan, X.; Wang, H.; Ye, S.; Yu, C.; He, Y.; Luo, H. MicroRNA-126 functions as a tumor suppressor in colorectal cancer cells by targeting CXCR4 via the AKT and ERK1/2 signaling pathways. Int. J. Oncol. 2014, 44, 203-210. [CrossRef]

156. Li, N.; Tang, A.; Huang, S.; Li, Z.; Li, X.; Shen, S.; Ma, J.; Wang, X. MiR-126 suppresses colon cancer cell proliferation and invasion via inhibiting RhoA/ROCK signaling pathway. Mol. Cell Biochem. 2013, 380, 107-119. [CrossRef]

157. Zhou, Y.; Feng, X.; Liu, Y.L.; Ye, S.C.; Wang, H.; Tan, W.K.; Tian, T.; Qiu, Y.M.; Luo, H.S. Downregulation of miR-126 is associated with colorectal cancer cells proliferation, migration and invasion by targeting IRS-1 via the AKT and ERK1/2 signaling pathways. PLoS ONE 2013, 8, e81203. [CrossRef]

158. Hansen, T.F.; Andersen, C.L.; Nielsen, B.S.; Spindler, K.-L.G.; Sørensen, F.B.; Lindebjerg, J.; Brandslund, I.; Jakobsen, A. Elevated microRNA-126 is associated with high vascular endothelial growth factor receptor 2 expression levels and high microvessel density in colorectal cancer. Oncol. Lett. 2011, 2, 1101-1106. [CrossRef]

159. Hansen, T.F.; Carlsen, A.L.; Heegaard, N.H.; Sorensen, F.B.; Jakobsen, A. Changes in circulating microRNA-126 during treatment with chemotherapy and bevacizumab predicts treatment response in patients with metastatic colorectal cancer. Br. J. Cancer 2015, 112, 624-629. [CrossRef]

160. Hiyoshi, Y.; Akiyoshi, T.; Inoue, R.; Murofushi, K.; Yamamoto, N.; Fukunaga, Y.; Ueno, M.; Baba, H.; Mori, S.; Yamaguchi, T. Serum miR-143 levels predict the pathological response to neoadjuvant chemoradiotherapy in patients with locally advanced rectal cancer. Oncotarget 2017, 8, 79201-79211. [CrossRef]

161. Gomes, S.E.; Pereira, D.M.; Roma-Rodrigues, C.; Fernandes, A.R.; Borralho, P.M.; Rodrigues, C.M.P. Convergence of miR-143 overexpression, oxidative stress and cell death in HCT116 human colon cancer cells. PLoS ONE 2018, 13, e0191607. [CrossRef] [PubMed]

162. Lertkiatmongkol, P.; Liao, D.; Mei, H.; Hu, Y.; Newman, P.J. Endothelial functions of platelet/endothelial cell adhesion molecule-1 (CD31). Curr. Opin. Hematol. 2016, 23, 253-259. [CrossRef] [PubMed]

163. Zhang, G.-J.; San, Y.-Z.; Zhang, H.-Q.; Zhang, J.-F.; Yang, Z.; Yu, Z.-F.; Kong, F.-Z.; Liu, H.-J.; Zhang, X.-L. MiR-590-5p as potential oncogenic microRNA of human colorectal cancer cells by targeting PTEN. Int. J. Clin. Exp. Pathol. 2017, 10, 1322-1330.

164. Kim, C.W.; Oh, E.T.; Kim, J.M.; Park, J.S.; Lee, D.H.; Lee, J.S.; Kim, K.K.; Park, H.J. Hypoxia-induced microRNA-590-5p promotes colorectal cancer progression by modulating matrix metalloproteinase activity. Cancer Lett. 2018, 416, 31-41. [CrossRef]

165. Li, H.; Miki, T.; Almeida, G.M.D.; Hanashima, C.; Matsuzaki, T.; Kuo, C.J.; Watanabe, N.; Noda, M. RECK in Neural Precursor Cells Plays a Critical Role in Mouse Forebrain Angiogenesis. iScience 2019, 19, 559-571. [CrossRef]

166. Zhang, W.; Xiong, Z.; Wei, T.; Li, Q.; Tan, Y.; Ling, L.; Feng, X. Nuclear factor 90 promotes angiogenesis by regulating HIF-1 $\alpha$ /VEGF-A expression through the PI3K/Akt signaling pathway in human cervical cancer. Cell Death Dis. 2018, 9, 276. [CrossRef]

167. Liu, S.C.; Chuang, S.M.; Hsu, C.J.; Tsai, C.H.; Wang, S.W.; Tang, C.H. CTGF increases vascular endothelial growth factor-dependent angiogenesis in human synovial fibroblasts by increasing miR-210 expression. Cell Death Dis. 2014, 5, e1485. [CrossRef]

168. Wang, L.-H.; Tsai, H.-C.; Cheng, Y.-C.; Lin, C.-Y.; Huang, Y.-L.; Tsai, C.-H.; Xu, G.-H.; Wang, S.-W.; Fong, Y.-C.; Tang, C.-H. CTGF promotes osteosarcoma angiogenesis by regulating miR-543/angiopoietin 2 signaling. Cancer Lett. 2017, 391, 28-37. [CrossRef]

169. Zhang, J.; Niu, Y.; Huang, C. Role of FoxM1 in the progression and epithelial to mesenchymal transition of gastrointestinal cancer. Recent Pat Anticancer Drug Discov. 2017, 12, 247-259. [CrossRef]

170. Chen, H.; Zou, Y.; Yang, H.; Wang, J.; Pan, H. Downregulation of FoxM1 inhibits proliferation, invasion and angiogenesis of HeLa cells in vitro and in vivo. Int. J. Oncol. 2014, 45, 2355-2364. [CrossRef]

171. Fu, Y.; Lin, L.; Xia, L. MiR-107 function as a tumor suppressor gene in colorectal cancer by targeting transferrin receptor 1. Cell Mol. Biol. Lett. 2019, 24, 31. [CrossRef] [PubMed]

172. Rokavec, M.; Li, H.; Jiang, L.; Hermeking, H. The p53/microRNA connection in gastrointestinal cancer. Clin. Exp. Gastroenterol 2014, 7, 395-413. [CrossRef] [PubMed]

173. Chen, H.-Y.; Lang, Y.-D.; Lin, H.-N.; Liu, Y.-R.; Liao, C.-C.; Nana, A.W.; Yen, Y.; Chen, R.-H. miR-103/107 prolong $W n t / \beta$-catenin signaling and colorectal cancer stemness by targeting Axin2. Sci. Rep. 2019, 9, 9687. [CrossRef] [PubMed] 
174. Molina-Pinelo, S.; Carnero, A.; Rivera, F.; Estevez-Garcia, P.; Bozada, J.M.; Limon, M.L.; Benavent, M.; Gomez, J.; Pastor, M.D.; Chaves, M.; et al. MiR-107 and miR-99a-3p predict chemotherapy response in patients with advanced colorectal cancer. BMC Cancer 2014, 14, 656. [CrossRef] [PubMed]

175. Shi, Y.-H.; Fang, W.-G. Hypoxia-inducible factor-1 in tumour angiogenesis. World J. Gastroenterol. 2004, 10, 1082-1087. [CrossRef]

176. Zhang, R.; Zhao, J.; Xu, J.; Wang, J.; Jia, J. miR-526b-3p functions as a tumor suppressor in colon cancer by regulating HIF-1 $\alpha$. Am. J. Transl. Res. 2016, 8, 2783-2789.

177. Vlachos, I.S.; Zagganas, K.; Paraskevopoulou, M.D.; Georgakilas, G.; Karagkouni, D.; Vergoulis, T.; Dalamagas, T.; Hatzigeorgiou, A.G. DIANA-miRPath v3.0: Deciphering microRNA function with experimental support. Nucleic. Acids Res. 2015, 43, W460-W466. [CrossRef]

178. Ma, Y.; Zhang, P.; Wang, F.; Zhang, H.; Yang, J.; Peng, J.; Liu, W.; Qin, H. miR-150 as a potential biomarker associated with prognosis and therapeutic outcome in colorectal cancer. Gut 2012, 61, 1447-1453. [CrossRef]

179. Zhao, Y.J.; Song, X.; Niu, L.; Tang, Y.; Song, X.; Xie, L. Circulating Exosomal miR-150-5p and miR-99b-5p as Diagnostic Biomarkers for Colorectal Cancer. Front. Oncol. 2019, 9. [CrossRef]

180. Liu, F.; Di Wang, X. miR-150-5p represses TP53 tumor suppressor gene to promote proliferation of colon adenocarcinoma. Sci. Rep. 2019, 9, 6740. [CrossRef]

181. Guo, Y.H.; Wang, L.Q.; Li, B.; Xu, H.; Yang, J.H.; Zheng, L.S.; Yu, P.; Zhou, A.D.; Zhang, Y.; Xie, S.J.; et al. Wnt/beta-catenin pathway transactivates microRNA-150 that promotes EMT of colorectal cancer cells by suppressing CREB signaling. Oncotarget 2016, 7, 42513-42526. [CrossRef] [PubMed]

182. Wang, J.; Yan, F.; Zhao, Q.; Zhan, F.; Wang, R.; Wang, L.; Zhang, Y.; Huang, X. Circulating exosomal miR-125a-3p as a novel biomarker for early-stage colon cancer. Sci. Rep. 2017, 7, 4150. [CrossRef] [PubMed]

183. Keeley, T.S.; Yang, S.; Lau, E. The Diverse Contributions of Fucose Linkages in Cancer. Cancers 2019, $11,1241$. [CrossRef] [PubMed]

184. Tang, L.; Zhou, L.; Wu, S.; Shi, X.; Jiang, G.; Niu, S.; Ding, D. miR-125a-5p inhibits colorectal cancer cell epithelial-mesenchymal transition, invasion and migration by targeting TAZ. Oncol. Targets Ther. 2019, 12, 3481-3489. [CrossRef]

185. Tong, Z.; Liu, N.; Lin, L.; Guo, X.; Yang, D.; Zhang, Q. miR-125a-5p inhibits cell proliferation and induces apoptosis in colon cancer via targeting BCL2, BCL2L12 and MCL1. Biomed. Pharmacother. 2015, 75, 129-136. [CrossRef]

186. Zhai, H.; Fesler, A.; Ba, Y.; Wu, S.; Ju, J. Inhibition of colorectal cancer stem cell survival and invasive potential by hsa-miR-140-5p mediated suppression of Smad2 and autophagy. Oncotarget 2015, 6, 19735-19746. [CrossRef]

187. Wang, X.D.; Lu, J.; Lin, Y.S.; Gao, C.; Qi, F. Functional role of long non-coding RNA CASC19/miR-140-5p/CEMIP axis in colorectal cancer progression in vitro. World J. Gastroenterol. 2019, 25, 1697-1714. [CrossRef]

188. Yu, L.; Lu, Y.; Han, X.; Zhao, W.; Li, J.; Mao, J.; Wang, B.; Shen, J.; Fan, S.; Wang, L.; et al. microRNA -140-5p inhibits colorectal cancer invasion and metastasis by targeting ADAMTS5 and IGFBP5. Stem. Cell Res. Ther. 2016, 7, 180. [CrossRef]

189. Mosakhani, N.; Lahti, L.; Borze, I.; Karjalainen-Lindsberg, M.L.; Sundstrom, J.; Ristamaki, R.; Osterlund, P.; Knuutila, S.; Sarhadi, V.K. MicroRNA profiling predicts survival in anti-EGFR treated chemorefractory metastatic colorectal cancer patients with wild-type KRAS and BRAF. Cancer Genet. 2012, 205, 545-551. [CrossRef]

190. Sheng, N.; Tan, G.; You, W.; Chen, H.; Gong, J.; Chen, D.; Zhang, H.; Wang, Z. MiR-145 inhibits human colorectal cancer cell migration and invasion via PAK4-dependent pathway. Cancer Med. 2017, 6, 1331-1340. [CrossRef]

191. Won, S.-Y.; Park, J.-J.; Shin, E.-Y.; Kim, E.-G. PAK4 signaling in health and disease: Defining the PAK4-CREB axis. Exp. Mol. Med. 2019, 51, 11. [CrossRef] [PubMed]

192. Yu, Y.; Nangia-Makker, P.; Farhana, L.; Majumdar, A.P.N. A novel mechanism of lncRNA and miRNA interaction: CCAT2 regulates miR-145 expression by suppressing its maturation process in colon cancer cells. Mol. Cancer 2017, 16, 155. [CrossRef] [PubMed]

193. Lang, H.L.; Hu, G.W.; Zhang, B.; Kuang, W.; Chen, Y.; Wu, L.; Xu, G.H. Glioma cells enhance angiogenesis and inhibit endothelial cell apoptosis through the release of exosomes that contain long non-coding RNA CCAT2. Oncol. Rep. 2017, 38, 785-798. [CrossRef] [PubMed] 
194. Bian, C.-X.; Shi, Z.; Meng, Q.; Jiang, Y.; Liu, L.-Z.; Jiang, B.-H. P70S6K 1 regulation of angiogenesis through VEGF and HIF-1 $\alpha$ expression. Biochem. Biophys. Res. Commun. 2010, 398, 395-399. [CrossRef]

195. Shinohara, H.; Kuranaga, Y.; Kumazaki, M.; Sugito, N.; Yoshikawa, Y.; Takai, T.; Taniguchi, K.; Ito, Y.; Akao, Y. Regulated Polarization of Tumor-Associated Macrophages by miR-145 via Colorectal Cancer-Derived Extracellular Vesicles. J. Immunol. 2017, 199, 1505-1515. [CrossRef]

196. Feng, C.; Zhang, L.; Sun, Y.; Li, X.; Zhan, L.; Lou, Y.; Wang, Y.; Liu, L.; Zhang, Y. GDPD5, a target of miR-195-5p, is associated with metastasis and chemoresistance in colorectal cancer. Biomed. Pharmacother. 2018, 101, 945-952. [CrossRef]

197. Guo, S.; Jiang, C.; Wang, G.P.; Li, Y.P.; Wang, C.Y.; Guo, X.Y.; Yang, R.H.; Feng, Y.; Wang, F.H.; Tseng, C.H.-Y.; et al. MicroRNA-497 targets insulin-like growth factor 1 receptor and has a tumour suppressive role in human colorectal cancer. Oncogene 2012, 32. [CrossRef]

198. Li, B.; Wang, S.; Wang, S. MiR-195 suppresses colon cancer proliferation and metastasis by targeting WNT3A. Mol. Genet. Genom. 2018, 293, 1245-1253. [CrossRef]

199. Qi, L.; Song, W.; Liu, Z.; Zhao, X.; Cao, W.; Sun, B. Wnt3a Promotes the Vasculogenic Mimicry Formation of Colon Cancer via Wnt/beta-Catenin Signaling. Int. J. Mol. Sci. 2015, 16, 18564-18579. [CrossRef]

200. Qi, L.; Sun, B.; Liu, Z.; Cheng, R.; Li, Y.; Zhao, X. Wnt3a expression is associated with epithelial-mesenchymal transition and promotes colon cancer progression. J Exp. Clin. Cancer. Res. 2014, 33, 107. [CrossRef]

201. Wu, Q.-B.; Sheng, X.; Zhang, N.; Yang, M.-W.; Wang, F. Role of microRNAs in the resistance of colorectal cancer to chemoradiotherapy. Mol. Clin. Oncol. 2018, 8, 528-532. [CrossRef] [PubMed]

202. Ma, W.; Yu, J.; Qi, X.; Liang, L.; Zhang, Y.; Ding, Y.; Lin, X.; Li, G.; Ding, Y. Radiation-induced microRNA-622 causes radioresistance in colorectal cancer cells by downregulating Rb. Oncotarget 2015, 6, 15984-15994. [CrossRef] [PubMed]

203. Wu, Y.; Jin, M.; Xu, H.; Shimin, Z.; He, S.; Wang, L.; Zhang, Y. Clinicopathologic significance of HIF-1 $\alpha$, CXCR4, and VEGF expression in colon cancer. Clin. Dev. Immunol. 2010, 2010, 537531. [CrossRef] [PubMed]

204. Romain, B.; Hachet-Haas, M.; Rohr, S.; Brigand, C.; Galzi, J.L.; Gaub, M.P.; Pencreach, E.; Guenot, D. Hypoxia differentially regulated CXCR4 and CXCR7 signaling in colon cancer. Mol. Cancer 2014, 13, 58. [CrossRef]

205. Li, T.; Jian, X.; He, H.; Lai, Q.; Li, X.; Deng, D.; Liu, T.; Zhu, J.; Jiao, H.; Ye, Y.; et al. MiR-452 promotes an aggressive colorectal cancer phenotype by regulating a Wnt/ $\beta$-catenin positive feedback loop. J. Exp. Clin. Cancer Res. 2018, 37, 238. [CrossRef] 